 \\ FOSTER 圆 WHEELER
}

TOPICAL REPORT

Project No.: 9-60550200

TITLE: FIRESIDE CORROSION TESTING OF CANDIDATE SUPERHEATER TUBE ALLOYS, COATINGS, AND CLADDINGSPhase II Field Testing

Principal Investigator and Program Manager: J. L. Blough

Topical Report, August 1996

Report Prepared by:

FOSTER WHEELER DEVELOPMENT CORPORATION

12 Peach Tree Hill Road

Livingston, New Jersey 07039

Prepared for:

OAK RIDGE NATIONAL LABORATORY

Oak Ridge, Tennessee $\mathbf{3 7 8 3 1}$

Managed by:

LOCKHEED MARTIN ENERGY RESEARCH CORPORATION for the

U. S. DEPARTMENT OF ENERGY

Under Contract No.: DE-AC05-960R22464 
This report has been reproduced directly from the best available copy.

Available to DOE and DOE contractors from the Office of Scientific and Technical Information, P.O. Box 62, Oak Ridge, TN 37831; prices available from (423) 576-8401.

Available to the public from the National Technical Information Service, U.S. Department of Commerce, 5285 Prot Royal Road, Springifeld, VA 22161.

This report was prepared as an account of work sponsored by an agency of the United States Government. Neither the United States Government nor any agency thereof, nor any of their employees, makes any warranty, expressed or implied or assumes any legal liability or responsibility for the accuracy, completeness, or usefulness of any information, apparatus, product, or process disclosed, or represents that its use would not infringe privately owned rights. Reference herein to any specific commercial product, process, or service by trade name, trademark, manufacturer, or otherwise, does not necessarily constitute or imply its endorsement, recommendation, or favoring by the United States Government or any agency thereof. The views and opinions of authors expressed herein do not necessarily state or reflect those of the United States Government or any agency thereof. 


\section{DISCLAIMER}

Portions of this document may be illegible electronic image products. Images are produced from the best available original document. 


\title{
FIRESIDE CORROSION TESTING OF CANDIDATE SUPERHEATER TUBE ALLOYS, COATINGS, AND
} CLADDINGS-PHASE II FIELD TESTING

\author{
Research sponsored by Department of Energy, Fossil Energy \\ Advanced Research and Technology Development Materials Program \\ [DOE/FE AA 151010 0, Work Breakdown Structure Element \\ ORNL-62X-SM-401C]
}

\author{
Report Prepared by \\ FOSTER WHEELER DEVELOPMENT CORPORATION \\ 12 Peach Tree Hill Road \\ Livingston, New Jersey 07039 \\ under \\ Subcontract 62X-SM-401C \\ for \\ OAK RIDGE NATIONAL LABORATORY \\ Oak Ridge, Tennessee 37831 \\ managed by \\ LOCKHEED MARTIN ENERGY RESEARCH CORPORATION \\ for the \\ U. S. Department of Energy \\ under Contract No. DE-AC05-960R22464
}




\section{Page}

List of Tables

List of Figures

iv

Abstract

Introduction

vi

Section 1

Phase I Results

1

Section II

Phase II Corrosion Probe Test Plan

Selection of Materials for Corrosion Probes

Field Corrosion Probe Design

2

Section III

Post-Exposure Analysis

Quarterly Examinations

Destructive Testing

Macroscopic Examination

Microscopic Examination and EDX Analysis

Wastage Determination

2

5

6

9

9

11

12

13

15

Discussion

Conclusions

References 


\section{LIST OF TABLES}

Table

Page

1

Composition of Alloys Examined

3

2

Chemical Composition of Candidate Alloys

5

3

Temperature Measurements

7

4

Estimated Average Midwall Specimen Temperatures

8

Coal Ash Chemistry - Gallatin

9

Deposit Analysis

10

7

Ultrasonic Measurement Results

11

8

Wall Loss at Measured Locations

13

Maximum Total Wastage of Specimens 


\section{LIST OF FIGURES}

(All figures are at the end of the report.)

Figure

1 Average thickness loss rate of alloys containing 14- to 30-percent chromium.

2 Average thickness loss rates of various monolithic alloys and claddings coated with ash containing $10 \mathrm{wt} \%$ alkali sulfates and exposed for 800 hours.

3 Average thickness loss rates of three intermetallic aluminides and two stainless steels exposed to a variety of environments.

$4 \quad$ Temperature plot

5 Side elevation of reheater at TVA Gallatin unit 2.

6 The two retracted probes on the left and the soot blower on the right are shown in the top photograph. The bottom photograph shows the cleaned probe for ultrasonic thickness measurements.

7 Shown are the probe samples after removal from the probe support pipe. The fireside half of the samples and the rings with the thermomcouples are shown.

8 The transverse cut sections after grit blasting are oriented with the 135-deg location at the top. The cooler set of samples is on the left.

9 The intergranular attack on the $O D$ and ID bottom of each pair of photomicrographs is shown for samples $85 \mathrm{H}-1$ and $85 \mathrm{H}-11$.

9 The intergranular attack on the OD top and ID bottom of each pair of photomicrographs is shown for samples $85 \mathrm{H}-1$ and $85 \mathrm{H}-11$.

10 Shown are EDX spectrums of subsurface chromium sulfides (top) and oxides (bottom) in sample $85 \mathrm{H}-1$ of Figure 9.

11 A few grain boundaries in sample $85 \mathrm{H}-11$ of Figure 9 show the top spectrum but most exhibit the bottom spectrum.

12 The slight intergranular penetration at low and high magnification is shown for the 347-2 sample.

13 The general corrosion on the OD and slight intergranular oxidation of the ID of the 347-12 sample is shown. 


\section{LIST OF FIGURES (cont)}

Figure

14 The outer layer of scale/deposit in sample 347-12 in Figure 13 exhibited the top spectrum. The subsurface sulfides in that sample are shown in the bottom spectrum.

15 Corrosion on the OD and intergranular oxidation on the ID of 253MA-14 are shown.

16 The spectrums of the outer layer, inner layer, and subsurface sulfides are shown in the top, middle, and bottom spectrums respectively for 253MA-14 in Figure 15.

17 Pitting and intergranular attack on the $\mathrm{OD}$ from the $800 \mathrm{H}-10$ and 20 samples are shown.

18 The spectrums of the outer layer, inner layer, and subsurface sulfides are shown in the top, middle, and bottom spectrums respectively for $800 \mathrm{HT}$ in Figure 17.

19 Alloys 310 modified, HR3C, and NF 709 are compared. The 310 modified showed the least attack.

20 The spectrums of the outer layer, inner layer, and subsurface sulfides are shown in the top, middle, and bottom spectrums respectively for NF 709 in Figure 19.

21 Only the ID attack of the lean stainless steel base material can be seen on the 67116 sample.

22 One mil of internal oxidation was observed on the OD of 690-17 (top). The ID attack of the lean stainless steel can be seen in the bottom photomicrograph.

23 Some slight surface attack can be seen on the $\mathrm{Fe}_{3} \mathrm{Al}-18$ sample. Also, cracks up to 5 mils deep can be seen in both samples.

24 Total wastage vs. the chromium level in the samples for the two different temperature bands is shown. 
In Phase I of this project, a variety of developmental and commercial tubing alloys and claddings was exposed to laboratory fireside corrosion testing simulating a superheater or reheater in a coal-fired boiler. Phase II (in situ testing) has exposed samples of 347, RA85H, HR3C, 253MA, Fe 3 Al + 5Cr, 310 modified, NF 709, 690 clad, and 671 clad for over 10,000 hours to the actual operating conditions of a $250-\mathrm{MW}$ coal-fired boiler. The samples were installed on air-cooled, retractable corrosion probes, installed in the reheater cavity, controlled to the operating metal temperatures of an existing and advanced-cycle, coal-fired boiler. Samples of each alloy are being exposed for $4000,12,000$, and 16,000 hours of operation.

The present results are for the metallurgical examination of the corrosion probe samples after approximately 4400 hours of exposure. 


\section{SECTION I}

\section{INTRODUCTION}

High-temperature fireside metal wastage in conventional coal-fired steam generators can be caused by gas-phase oxidation or liquid-phase coal-ash corrosion. Gas-phase oxidation is usually not a problem if tube and support materials are selected for their oxidation resistance at operating temperatures and for spalling, flaking, or other reactions to their environment. Coal-ash corrosion, on the other hand, usually results in accelerated attack and rapid metal wastage-even of stainless steels. The cause of this type of corrosion is generally accepted as the presence of liquid sulfates on the surface of the metal beneath an overlying ash deposit $^{1-4}$.

While substantial progress has been achieved through laboratory testing, actual utility service exposures are evidently necessary to verify any conclusions drawn from laboratory testing. A number of important environmental parameters cannot be fully simulated in the laboratory ${ }^{5}$ :

- The actual composition of the deposits formed on the tubes is more complex than the composition of the simulated ash.

- The $\mathrm{SO}_{3}$, formed by heterogeneous reaction on cooled surfaces, is variable.

- Very large temperature gradients occur within the ash deposits.

- The ash and fuel gas move past tubes at high velocity; the rate varies with design.

- The composition of the corrosive deposits changes with time.

- Metal and flue gas temperatures fluctuate.

- Fly-ash erosion removes the protective oxides, exposing a clean surface to fresh ash.

Foster Wheeler Development Corporation (FWDC) has performed a number of literature reviews and recent updates discussing the variables affecting the corrosion mechanism ${ }^{6.8}$. Additionally, Foster Wheeler has conducted two sizable research projects-one a laboratory and in situ field testing at three utilities of commercially available alloys ${ }^{5,12 \cdot 14}$ and this program (ORNL-FW2), combining laboratory and field testing to more completely cover the controlling variables for a longer duration ${ }^{10}$. 


\section{SECTION II}

\section{PHASE I RESULTS}

In Phase I of this ORNL program, "Fireside Corrosion Testing of Candidate Superheater Tube Alloys, Coatings, and Claddings," 20 commercial and developmental alloys listed in Table 1 were evaluated ${ }^{10}$. The coupons of the metals were exposed to multiple types of synthetic coal ash and synthetic flue gases at 650 and $700^{\circ} \mathrm{C}\left(1202\right.$ and $\left.1292^{\circ} \mathrm{F}\right)$ for up to 800 hours. The average thickness loss rate for 14 - to 48 -percent chromium-containing alloys and the intermetallic aluminides are shown in Figures 1 through 3.

Chromium content was found to be the largest factor in determining the resistance of an alloy to liquid coal-ash corrosion. For stainless steels and nickel alloys, additions of chromium up to 25 percent provide increased resistance to coal-ash attack; however, above the 25-percent chromium level, there appears to be minimal benefit from more chromium, possibly because of the higher nickel content of those alloys.

Molybdenum, on the other hand, may be detrimental to corrosion resistance. Silicon and aluminum were also beneficial, but to a lesser extent. The iron aluminide intermetallics also show a chromium dependence. Aluminides containing 5-percent chromium performed markedly better overall than those containing 2-percent chromium. The more resistant alloys show lower corrosion rates at longer exposure times, indicating the formation of a passive layer; the less-resistant alloys exhibit increasing corrosion rates at longer exposures. Lowerchromium alloys generally suffered greater wastage rates at the higher testing temperature $\left[700^{\circ} \mathrm{C}\left(1292^{\circ} \mathrm{F}\right)\right]$, while higher-chromium alloys suffered the same amount of wastage at 650 $(1202)$ as at $700^{\circ} \mathrm{C}\left(1292^{\circ} \mathrm{F}\right)$.

Both the alkali content in the ash and $\mathrm{SO}_{2}$ concentration in the flue gas affect the corrosivity of the alkali-iron-trisulfates in the ash layer. An increase in either resulted in a more corrosive environment and higher wastage rates.

\section{SECTION III}

\section{PHASE ॥ CORROSION PROBE TEST PLAN}

In this project, the field tests comprise corrosion probe testing, coal characterization, and deposit/corrosion product analysis. The coals have been analyzed to provide fuel characterization, a deposit analysis data bank, and possibly a corrosivity index for predicting corrosivity under various combustion conditions. The equipment and the procedures for this phase 
Table 1. Composition of Alloys Examined

\begin{tabular}{|c|c|c|c|c|c|c|c|c|c|c|c|c|}
\hline Alloy & $\mathbf{F e}$ & $\mathbf{N i}$ & Cr & Mo & c & si & Mn & Al & $\mathbf{N}$ & $\mathbf{s}$ & $\mathbf{P}$ & Other \\
\hline $\mathrm{Fe}_{3} \mathrm{Al}-2 \mathrm{Cr}$ & 81.86 & & 2.19 & & & & & 15.93 & & & & B 0.01 \\
\hline $\mathrm{Fe}_{3} \mathrm{Al}-6 \mathrm{Cr}$ & 77.5 & & 5.6 & & & & & 15.9 & & & & \\
\hline$\left.(\mathrm{FeNi})_{3}\right) \mathrm{Al}$ & 11.7 & 70.1 & 7.2 & & & & & 11.0 & & & & \\
\hline $\begin{array}{l}\text { Modified } 316 \\
\text { (LSS)' }^{3}\end{array}$ & Bal & 16.83 & 14.27 & 2.26 & 0.079 & 0.23 & 1.77 & 0.06 & 0.012 & 0.01 & 0.037 & $\begin{array}{l}\text { V } 0.62, \text { Nb } 0.1 \text {, } \\
\text { Ti } 0.21\end{array}$ \\
\hline 17-14 CuMo & Bal & 14.08 & 16.37 & 1.95 & 0.078 & 0.72 & 0.88 & & & 0.005 & 0.023 & $\mathrm{Cu} 3.34$ \\
\hline Type $347^{\circ}$ & Bal & 10.3 & 17.5 & & 0.08 & 1.3 & 1.6 & & & 0.03 & 0.045 & $\mathrm{Nb} 0.8$ \\
\hline RA85H & Bal & 15.26 & 18.50 & 0.06 & 0.24 & 3.90 & 0.50 & 0.70 & 0.10 & & 0.015 & Cu 0.39 \\
\hline $\begin{array}{l}\text { Modified } \\
80 \mathrm{OH}\end{array}$ & Bal & 31.08 & 20.87 & 2.01 & 0.097 & & 1.93 & 0.02 & 0.01 & 0.013 & 0.003 & $\begin{array}{l}\text { Nb } 0.19, \text { Ti } 0.29 \text {, } \\
\text { V } 0.47\end{array}$ \\
\hline NF $709^{* t}$ & Bal & 24.3 & 21.6 & $\begin{array}{l}1.0- \\
2.0\end{array}$ & $<0.2$ & 0.7 & $<1.6$ & & $\begin{array}{l}0.05- \\
0.02\end{array}$ & $<0.01$ & $<0.03$ & $\begin{array}{l}\text { Ta } 0.68, \mathrm{Nb} 0.07 \\
\text { W } 2.45, \text { B } 0.01\end{array}$ \\
\hline Haynes 566 & Bal & 22.1 & 21.55 & 2.83 & 0.1 & 0.4 & 0.95 & 0.13 & 0.16 & 0.002 & 0.006 & $\mathrm{Nb} 0.45$ \\
\hline $\mathrm{HR}^{\mathrm{H}} \mathrm{C}^{\dagger}$ & Bal & 20.45 & 24.95 & & 0.06 & 0.42 & 1.28 & & 0.23 & 0.0001 & 0.013 & \\
\hline $690 / 316$ & 9.09 & 57.3 & 31.65 & $<0.05$ & 0.048 & 0.26 & 0.17 & & & 0.002 & $<0.005$ & \\
\hline $690 / 800 \mathrm{H}$ & 9.13 & 57.3 & 31.50 & $<0.05$ & 0.049 & 0.26 & 0.17 & & & 0.002 & $<0.005$ & \\
\hline $690^{\circ}$ & 9.6 & Bal & 30.0 & & 0.03 & & & & & & & \\
\hline $\mathrm{CR} 35 \mathrm{~A}^{\dagger}$ & 17.7 & 43.8 & 37.3 & & & & 0.2 & & & & & \\
\hline 72 Clad Lss & 0.27 & 55.89 & 43.73 & & 0.01 & 0.07 & 0.03 & & & 0.001 & & \\
\hline $72 \mathrm{Clad} 800 \mathrm{H}$ & 0.55 & 55.3 & 43.00 & 0.067 & 0.041 & 0.15 & 0.025 & & & 0.001 & 0.006 & \\
\hline $\begin{array}{l}671 \text { Clad } \\
\text { LSS }^{\prime}\end{array}$ & & Bal & 48.5 & $<0.05$ & 0.057 & 0.11 & $<0.10$ & $<0.05$ & 0.0095 & 0.003 & 0.002 & $\begin{array}{l}\mathrm{Ti} 0.46, \mathrm{Nb} \\
<0.05, \mathrm{Cu}<0.05\end{array}$ \\
\hline $671^{\circ}$ & & Bal & 48.0 & & 0.05 & & & & & & & Ti 0.35 \\
\hline Sandvik $28^{\dagger}$ & Bal & 31.19 & 26.94 & 3.36 & 0.011 & 0.15 & 0.67 & & 0.045 & 0.003 & 0.014 & Cu 1.00 \\
\hline -Typical & \multicolumn{12}{|c|}{ †Supplied by FWDC; all other supplied by ORNL } \\
\hline
\end{tabular}


have been previously used and perfected at three different utilities for over 3 years of in situ testing at each station.

The utility for test exposures should be burning an aggressive fuel to adequately evaluate the candidate alloys. The coal being burned at Tennessee Valley Authority's (TVA's) Gallatin Station had been previously analyzed, and numerous corrosion indices predicted high corrosivity in addition to the fact that installed T22 and Type 304SS tubing experienced about 7 years of life in the superheaters and reheaters of units 1 and 2 .

\section{Selection of Materials for Corrosion Probes}

FWDC laboratory-tested 20 different materials ${ }^{10}$. Because this quantity was impractical from both an economic and a probe-length standpoint, fewer (the ten listed in Table 2) had to be selected for the field tests. These materials provide a range of compositions and cost for both the commercially available and developmental alloys and claddings.

Table 2. Chemical Composition of Candidate Alloys (\%)

\begin{tabular}{|c|c|c|c|}
\hline Alloy & $\mathrm{Cr}$ & $\mathbf{N i}$ & Others \\
\hline Type 347 & $17-19$ & $9-13$ & $\begin{array}{l}(\mathrm{Nb}+\mathrm{Ta})=10 \times \mathrm{C} \\
(\mathrm{min} .)\end{array}$ \\
\hline $85 \mathrm{H}$ & 18 & 15 & $\mathrm{Al}=1, \mathrm{Si}=3.9$ \\
\hline NF 709 & 20 & 25 & $\begin{array}{l}M o=1.5, M n=1.0, \mathrm{Si} \\
=0.6\end{array}$ \\
\hline $690 \mathrm{Clad} / \mathrm{LSS}$ & 30 & 58 & \\
\hline $671 \mathrm{Clad} / \mathrm{LSS}{ }^{\circ}$ & 48 & 52 & \\
\hline $\begin{array}{l}\mathrm{Fe}_{3} \mathrm{Al}+5 \% \\
\mathrm{Cr}\end{array}$ & 5 & $\cdots$ & $A l=17$ \\
\hline HR3C & 25 & 20 & $\mathrm{Nb}=0.4$ \\
\hline 253 MA & 21 & 11 & $S i=1.7$ \\
\hline 310 modilied & 25 & 20 & $\mathrm{Ta}=1.5$ \\
\hline $800 \mathrm{HT}$ & 21 & 32 & $A l+T i=1$ \\
\hline
\end{tabular}




\section{Field Corrosion Probe Design}

The corrosion probes were designed to provide realistic exposures of metal samples to both actual boiler environments and also at the higher anticipated metal temperatures of an advanced plant. The parameters are independent from the main boiler, removal without a boiler outage, and a fail-safe design, one that removes the probe from the boiler if there are any malfunctions. With these features, years of testing will not be compromised with a sudden system overheating.

The probes are being exposed for $4000,12,000$, and 16,000 hours. This is being accomplished by utilizing two probe test locations. At one test location, the probe is being exposed for 16,000 hours. At the other test location, the probe will be removed after 4000 hours and a new probe inserted for the remaining 12,000 hours.

Each probe is a $2.56-\mathrm{m}$ (8.4-ft)-long, $60.20-\mathrm{mm}(2.37-\mathrm{in})-.O D$ tube that extends into the furnace for approximately $2.3 \mathrm{~m}(7.6 \mathrm{ft})$. Ring samples [38.1 $\mathrm{mm}(1.5 \mathrm{in}$.$) wide] of the$ candidate alloys listed in Table 2 were installed at the end of the probe farthest from the furnace wall. The probe is cooled by air that flows in the annular region between the probe tube ID and the tapered inner tube OD. The tapered inner tube was designed to obtain two bands of temperature on the outer surface of the samples. The alloy samples were duplicated in such a manner as to expose each alloy to a temperature in each of the temperature bands [621 to $677^{\circ} \mathrm{C}\left(1150\right.$ to $\left.1250^{\circ} \mathrm{F}\right)$ and 677 to $727^{\circ} \mathrm{C}\left(1250\right.$ to $\left.1340^{\circ} \mathrm{F}\right)$ ].

Each probe has a retraction mechanism and three K-type thermocouples in duplicate to monitor the mean tube wall at the beginning and end of each test section group. $A$ 19.95-mm (3/4-in.) OD $\times$ 6-ft-long thermowell with sheathed thermocouple was mounted between the corrosion probes to measure flue gas temperature. Each probe has its own cooling-air control valve.

The control system monitors the selected control thermocouple and modulates the airflow to maintain an average surface metal temperature for each temperature band. The probes retract automatically if failure of the cooling-air supply system or any other malfunction (instrument signal, power failure, or computer failure) causes the probe temperature to exceed the set limit of $746^{\circ} \mathrm{C}\left(1375^{\circ} \mathrm{F}\right)$ for 2 minutes. FWDC personnel access the field computer automatically for probe status and temperature data each morning at 6 a.m. or manually through its modem. A typical monthly plot of the thermocouples is shown in Figure 4. The number of hours in various temperature bands are counted as illustrated in Table 3 , and the effective temperature over the complete test period is then obtained. Once 
Table 3. Temperature Measurements *

\begin{tabular}{|c|c|c|c|c|c|c|c|}
\hline \multirow{2}{*}{$\begin{array}{c}\text { Temperature } \\
\text { Band }\end{array}$} & \multicolumn{3}{|c|}{ Upper } & \multicolumn{3}{|c|}{ Lower } & \multirow{2}{*}{$\begin{array}{c}\text { Flue } \\
\text { Gas } \\
1\end{array}$} \\
\hline & $1 / 2$ & $3 / 4$ & $5 / 6$ & $1 / 2$ & $3 / 4$ & $5 / 6$ & \\
\hline $1-900$ & 826 & 827 & 827 & 826 & 827 & 828 & 701 \\
\hline $901-1000$ & 5 & 4 & 4 & 5 & 4 & 9 & 5 \\
\hline $1001-1100$ & 5 & 5 & 69 & 13 & 5 & 105 & 9 \\
\hline $1101-1150$ & 2 & 4 & 2716 & 3 & 2 & 2141 & 8 \\
\hline $1151-1175$ & 2 & 2 & 1172 & 2 & 2 & 1796 & 3 \\
\hline $1176-1200$ & 1 & 4 & 414 & 2 & 2 & 314 & 16 \\
\hline $1201-1225$ & 4 & 15 & 66 & 3 & 18 & 61 & 28 \\
\hline $1226-1250$ & 11 & 299 & 8 & 6 & 1983 & 8 & 40 \\
\hline $1251-1275$ & 26 & 4002 & 1 & 27 & 2283 & 1 & 74 \\
\hline $1276-1300$ & 115 & 113 & 0 & 122 & 105 & 0 & 107 \\
\hline $1301-1325$ & 869 & 3 & 0 & 814 & 23 & 0 & 108 \\
\hline $1326-1350$ & 1947 & 1 & 0 & 2553 & 8 & 0 & 137 \\
\hline $1351-1375$ & 1314 & 0 & 0 & 790 & 0 & 0 & 199 \\
\hline $1376-1400$ & 146 & 0 & 0 & 82 & 0 & 0 & 259 \\
\hline $1401-1500$ & 6 & 0 & 0 & 17 & 1 & 0 & 1330 \\
\hline $1501-1600$ & 0 & 0 & 0 & 0 & 0 & 0 & 1734 \\
\hline $1601-1700$ & 0 & 0 & 0 & 0 & 0 & 0 & 517 \\
\hline $1701-1800$ & 0 & 0 & 0 & 0 & 0 & 0 & 3 \\
\hline $1801-1900$ & 0 & 0 & 0 & 0 & 0 & 0 & 0 \\
\hline $1901-2000$ & 0 & 0 & 0 & 0 & 0 & 0 & 0 \\
\hline $2001-3000$ & 0 & 0 & 0 & 0 & 0 & 0 & 0 \\
\hline $1101-1400$ & 4436 & 4441 & 4376 & 4402 & 4426 & 4321 & 4560 \\
\hline Wtd. Avg. T.t & 1339 & 1261 & 1143 & 1336 & 1252 & 1147 & 1485 \\
\hline Total Hours & 5276 & $\mathbf{5 2 7 6}$ & 5276 & 5263 & 5263 & 5263 & 5276 \\
\hline \multicolumn{8}{|c|}{$\begin{array}{l}\text { From } 11 / 16 / 94 \text { at } 20: 20: 54 \text { to } 06 / 28 / 95 \text { at } 06: 15: 10 \text {. } \\
\text { tWeighted average temperature (Wtd. Avg. T) is defined as the sum of the products } \\
\text { of time and the average temperature in the band divided total time in the bands. For } \\
\text { probes the bands from } 1100 \text { to } 1400 \text { are used. For flue gas the bands from } 1100 \\
\text { to } 3000 \text { are used. }\end{array}$} \\
\hline
\end{tabular}


the effective temperature is obtained for the ends of each test section, the effective temperature for each alloy sample can be calculated from the thermal properties of the alloys. The results are given in Table 4.

The locations in this plant (shown in Figure 5) were chosen because of cavity access and because they best represent the locations for the reheater or superheater outlet on the "Advanced Cycle" unit.

The ideal coal-ash corrosion probe exposure is when only one coal is being burned at the plant. This practice is not common at many utilities since most have multiple long-term coal contracts; in fact, many are buying coal on the spot market. Gallatin burns a number of eastern high-sulfur coals, mainly Island Creek, Warrior, Dotiri, Pattiki, and Constain, which are known to be corrosive and prone to alkali-iron-trisulfate formation. The coal analysis for the Constain coals burned as the primary fuel during the present 4000 hours is given in Table 5 . The Borio Index for these coals typically range from 2.0 to 4.1 , and the chloride level is 450 to $3000 \mathrm{ppm}$.

Table 4. Estimated Average Midwall Specimen Temperatures

\begin{tabular}{|c|l|c|c|l|c|}
\hline Sample & Material & Temperature & Sample & Material & Temperature \\
\hline 1 & $85 \mathrm{H}$ & 1156 & 11 & $85 \mathrm{H}$ & 1260 \\
\hline 2 & 347 & 1166 & 12 & 347 & 1267 \\
\hline 3 & $\mathrm{NF} \mathrm{709}$ & 1175 & 13 & NF 709 & 1275 \\
\hline 4 & $253 \mathrm{MA}$ & 1185 & 14 & $253 \mathrm{MA}$ & 1282 \\
\hline 5 & $\mathrm{HR} 3 \mathrm{C}$ & 1194 & 15 & $\mathrm{HR} 3 \mathrm{C}$ & 1290 \\
\hline 6 & 671 & 1204 & 16 & 671 & 1294 \\
\hline 7 & 690 & 1213 & 17 & 690 & 1305 \\
\hline 8 & Fe ${ }_{3} \mathrm{Al}$ & 1223 & 18 & Fe $\mathrm{Al}_{3} \mathrm{Al}$ & 1312 \\
\hline 9 & 310 & 1232 & 19 & 310 & 1320 \\
\hline 10 & $80 \mathrm{HT}$ & 1242 & 20 & $800 \mathrm{HT}$ & 1327 \\
\hline
\end{tabular}


Table 5. Coal Ash Chemistry - Gallatin

\begin{tabular}{|c|c|c|c|}
\hline Description & Constain & Description & Constain \\
\hline \multicolumn{2}{|c|}{ Proximate, wt \% } & \multicolumn{2}{|c|}{ Coal Basis, \% } \\
\hline Fixed Carbon & 55.9 & $\mathrm{Fe}_{2} \mathrm{O}_{3}$ & 1.6 \\
\hline Volatile Matter & 34.93 & $\mathrm{CaO}$ & 0.134 \\
\hline \multirow[t]{2}{*}{ Ash } & 9.16 & $\mathrm{MgO}$ & 0.07 \\
\hline & & $\begin{array}{l}\mathrm{CaO}+\mathrm{MgO} \\
\text { (Eq.) }\end{array}$ & 0.23 \\
\hline \multicolumn{2}{|c|}{ Ultimate, Wt $\%$} & \multicolumn{2}{|c|}{ Acid Soluble, ppm(w) } \\
\hline Carbon & 76.2 & $\mathrm{Na}_{2} \mathrm{O}$ & 422 \\
\hline Hydrogen & 5.13 & $\mathrm{~K}_{2} \mathrm{O}$ & 392 \\
\hline Oxygen & 6.15 & $\begin{array}{l}\mathrm{K}_{2} \mathrm{O} \text { (as } \mathrm{Na}_{2} \mathrm{O} \\
\text { Eq.) }\end{array}$ & 255 \\
\hline Nitrogen & 1.63 & $\mathrm{MgO}$ & 336 \\
\hline Sulfur & 1.73 & $\mathrm{CaO}$ & 604 \\
\hline Ash & 9.16 & Chloride & 2750 \\
\hline HHV, Btu/lb & 13,517 & \multicolumn{2}{|c|}{ Indices } \\
\hline \multicolumn{2}{|c|}{ Sulfur, \% } & Borio Index & 3.0 \\
\hline Sulfatic & 0 & & \\
\hline Pyritic & 1.2 & & \\
\hline Organic & 0.53 & & \\
\hline Total & 1.73 & & \\
\hline
\end{tabular}

SECTION IV

POST-EXPOSURE ANALYSIS

\section{Quarterly Examinations}

During the quarterly inspections, FWDC personnel at the site manually retract the probes, selectively remove deposits, and make ultrasonic wall thickness measurements on the 4000- and 12,000-hour probe samples of the probe set. The 16,000-hour probe is left untouched at this time. The quarterly inspections provide preliminary nondestructive corrosion 
data before the three destructive examinations. With these data, corrosion can be tracked, and a total loss of data can be avoided if there is a catastrophic failure. The automaticretraction feature, if cooling air is lost and test specimen temperatures become excessive, minimizes the possibility of such a catastrophic failure.

The laboratory analysis of the removed deposits at FWDC characterizes the composition and determines whether alkali sulfates are present and aids in interpreting the effect of fuel changes on coal-ash corrosion. An example of the chemical analysis for the coal ash collected on the corrosion probe is given in Table 6.

On March 8, 1995, the probes were pulled for maintenance and quarterly ultrasonic inspection of the 4000 -hour probe. On each ring the measurements were taken at two cleaned locations of approximately $10: 00$ and 2:00 with the oncoming flue gas at 12:00. Figure 6 (top) shows the two probes in the retracted position. The nearby soot blower can be seen to the right of the corrosion probes. The 4000-hour probe was carefully cleaned las shown in Figure 6 (bottom)] with a wire wheel and/or sanding disk to remove the deposit and scale without removing any metal. Thickness losses were calculated, and the range of wall loss is given in Table 7. These thickness losses were obtained from an ultrasonic reading and, therefore, should be taken as only relative values. They do not include any internal penetration measurements and are not as accurate as micrometer and microscopic examination.

Table 6. Deposit Analysis

\begin{tabular}{|l|c|l|c|}
\hline \multicolumn{1}{|c|}{ Element } & $\begin{array}{c}\text { As Oxide, } \\
\%\end{array}$ & \multicolumn{1}{|c|}{ Element } & $\begin{array}{c}\text { As Oxide, } \\
\%\end{array}$ \\
\hline Silicon Dioxide & 46.7 & Sodium Oxide & $<0.1$ \\
\hline $\begin{array}{l}\text { Aluminum } \\
\text { Oxide }\end{array}$ & 24.5 & Potassium Oxide & 3.1 \\
\hline $\begin{array}{l}\text { Titanium } \\
\text { Dioxide }\end{array}$ & 1.6 & Sulfur Trioxide & 0.7 \\
\hline Ferric Oxide & 18.5 & Phos. Pentoxide & 0.3 \\
\hline Calciuim Oxide & 2.0 & Loss on Ignition & 1.84 \\
\hline $\begin{array}{l}\text { Magnesium } \\
\text { Oxide }\end{array}$ & 0.7 & & \\
\hline
\end{tabular}


Table 7. Ultrasonic Measurement Results (mils) 4000-Hour Probe

\begin{tabular}{|l|c|c|}
\hline \multicolumn{1}{|c|}{ Material } & $\begin{array}{c}\text { Test Section 1 } \\
\text { Thickness Loss }\end{array}$ & $\begin{array}{c}\text { Test Section 2 } \\
\text { Thickness Loss }\end{array}$ \\
\hline $800 \mathrm{HT}$ & $1-4$ & -- \\
\hline $800 \mathrm{HT}$ & $0-6$ & $0-3$ \\
\hline $85 \mathrm{H}$ & $0-4$ & $0-2$ \\
\hline 347 & $0-2$ & $0-6$ \\
\hline $\mathrm{NF} \mathrm{709}$ & 0 & $0-5$ \\
\hline $253 \mathrm{MA}$ & $4-5$ & $2-6$ \\
\hline 671 & $6-14$ & $8-9$ \\
\hline 690 & 0 & $0-5$ \\
\hline Fe $\mathrm{Al}_{3} \mathrm{Al}$ & 0 & 0 \\
\hline 310 & $0-2$ & $0-4$ \\
\hline $800 \mathrm{HT}$ & $0-5$ & 0 \\
\hline $800 \mathrm{HT}$ & -- & 0 \\
\hline
\end{tabular}

The thickness losses for each alloy are generally higher, as would be expected, in the hotter Section 1 samples vs. the Section 2 sample. There are some exceptions, but these results are only interim ultrasonic measurements.

There was quite a variation in the thickness readings and, therefore, no elemental dependencycould be determined. The stability of the readings on the 671 sample at the earlier inspection was a problem, but that was later resolved with a different U-T meter at the later inspection.

Again, these ultrasonic readings every 2000 hours are a check on the status of the alloys and determine relative losses, not absolute measurements which can only be done when microscopic examination for penetration is performed.

\section{Destruative Testing}

At approximately 4400 hours, one probe was removed, and post-exposure metallurgical evaluation was performed including:

- Visual examination and selective photographic documentation 
- Selective removal of deposits

- Disassembly of probes

- Cutting of two transverse sections through the center of the ring sample

- Light grit blasting of one transverse ring section of each sample

- Visual examination of the cleaned samples

- Wall thickness measurements at 45-deg points or maximum loss areas on the leading $180-$ deg side of cleaned transverse ring from each alloy

- Mounting of the uncleaned ring samples to analyze the scale/deposit

- Microscopic measurement of the penetration and calculation of total metal loss

- Selective scanning electron microscopy/energy-dispersive x-ray (SEM/EDX) examination to analyze corrosion mechanism.

\section{Macroscopic Examination}

The probe was cut to remove the two test sections as shown in Figure 7. Each of the sample rings was cut into two $1 / 4$-in.-long transverse rings. One was lightly grit blasted and used for thickness measurements while the other was mounted for microscopic and SEM/EDX analysis.

The appearance of the transverse cross sections used for the wall thickness measurements is shown in Figure 8. As illustrated, the middle of the sections is approximately the 135-deg location. [Note: Axially oriented grooves, evident at the 180-deg location, are artifacts believed to have been caused by a roller in the guide assembly.] Shallow pitting or surface irregularity is apparent in samples $1(85 \mathrm{H}), 2(347)$, and $4(253 \mathrm{MA})$ in the lower temperature group, and samples $12(347)$ and 14 (253MA) in the high-temperature group. Post-exposure wall thickness readings were made at the 45-, 135-, and 270-deg locations, and the calculated wall loss at the three locations is presented in Table 8. [Note: Subsequent microscopic examination revealed most of the wall loss in samples 6, 7, 16, and 17 (671 and 690 clad on LSS) resulted from oxidation of the inside surface and not corrosion of the outside surface. Oxidation of the inside surface also contributed to the wall loss in samples 12 and 14.] Discounting the high values in samples 6, 7, 16, and 17 because of oxidation of the ID surface, the wall loss values of the specimens in each group were relatively minor. In correlation with their surface appearance in Figure 8, samples 2 (347) and 4 (253MA) in the lower-temperature group and samples 12 (347) and 14 (253MA) in the higher-temperature group exhibited higher values than most of the other alloys. Contrarily, the shallow pitting in sample $1(85 \mathrm{H})$ was not indicated by a wall thickness loss, nor was the 1.6-mil wall loss at 
Table 8. Wall Loss at Measured Locations

\begin{tabular}{|c|c|c|c|c|c|c|c|c|c|}
\hline \multirow{2}{*}{ Sample } & \multirow{2}{*}{ Material } & \multicolumn{3}{|c|}{ Wall Loss* (mils) } & \multirow{2}{*}{ Sample } & \multirow{2}{*}{ Material } & \multicolumn{3}{|c|}{ Wall Loss* (mils) } \\
\hline & & $45^{\circ}$ & $135^{\circ}$ & $270^{\circ}$ & & & $45^{\circ}$ & $135^{\circ}$ & $270^{\circ}$ \\
\hline 1 & $85 \mathrm{H}$ & -0.5 & -1.0 & -0.5 & 11 & $85 \mathrm{H}$ & 0.3 & 0.5 & 0.1 \\
\hline 2 & 347 & 0 & 2.7 & -0.2 & 12 & 347 & 2.0 & 0.9 & 0.3 \\
\hline 3 & NF 709 & 0 & 0 & 0 & 13 & NF 709 & 1.6 & 0.3 & -0.3 \\
\hline 4 & $253 \mathrm{MA}$ & 1.2 & 1.9 & -0.1 & 14 & $253 \mathrm{MA}$ & 1.2 & 0.1 & 0.3 \\
\hline 5 & HR3C & 0.8 & 0.9 & -0.2 & 15 & HR3C & 0.8 & 0.6 & 0 \\
\hline 6 & 671 & 4.0 & 2.9 & 0 & 16 & 671 & 9.7 & 3.1 & 1.9 \\
\hline 7 & 690 & 1.1 & -1.6 & 0.5 & 17 & 690 & 4.9 & 3.3 & 0.9 \\
\hline 8 & $\mathrm{Fe}_{3} \mathrm{Al}$ & -4.0 & -3.0 & -1.0 & 18 & $\mathrm{Fe}_{3} \mathrm{Al}$ & -1.0 & -1.0 & -2.0 \\
\hline 9 & $310 t$ & 0 & -0.1 & 0.4 & 19 & $310 t$ & 0.1 & -0.2 & 0.1 \\
\hline 10 & $800 \mathrm{HT}$ & 0.5 & -0.2 & 0 & 20 & $800 \mathrm{HT}$ & 0.5 & 0 & 0 \\
\hline
\end{tabular}

the 45-deg location in sample 13 (NF 709) indicated by the appearance of the transverse cross section in Figure 8.

\section{Microscopic Examination and EDX Analysis}

Short sections from the 45-, 135-, and 270-deg locations of the samples were prepared for microscopic examination. Photomicrographs depicting various surface conditions (both $O D$ and ID) in the samples are presented in Figures 9 through 13. A summary of the examination follows.

85H (Figures 9 through 11) - Both 85H samples exhibited intergranular penetration in the outside surface to a depth of approximately 2.5 mils. Sample 1 , which operated at a lower temperature than sample 11 (1156 vs. $1260^{\circ} \mathrm{F}$ ), displayed more areas of subsurface attack (which is consistent with the observation of the shallow pitting in this sample in Figure 8). EDX analysis (Figure 10) revealed the light gray material in the grain boundaries and pits in sample 1 was chromium-rich oxide with varying amounts of sulfur. The material at similar locations in sample 11 (Figure 11) was also a chromium-rich oxide but appeared to have less sulfur than the material in specimen 1 . Interestingly, the outside surface at the 270-deg location in sample 11 also exhibited intergranular penetration to a depth of 2 mils. 
Both samples also displayed intergranular penetration in the inside surface (Figure 9). The depth of penetration was 2 mils in sample 1 and 2.5 mils in sample 11 . This type of penetration is not anticipated to have affected the wall thickness measurements.

347 (Figures 12 and 13) - Both 347 samples contained a scale/deposit in the corroded areas. Sulfide penetration to a depth of approximately 0.5 mil below the scale/deposit was also evident in each sample. The outer layer of the scale/deposit (Figure 14) was predominantly iron oxide with embedded fly-ash particles; the inner layer was a chromium-rich oxide and contained a small amount of sulfur. The sulfides contained iron, manganese, and chromium.

As illustrated in the bottom photomicrographs in Figure 12, the inside surface of sample 12 contained a thin oxide with an average thickness of approximately 0.5 mil. This was similar for sample 2.

253MA (Figure 15) - The 253MA sample in the hotter section (sample 14) contained a two-layer scale/deposit, with subsurface sulfide penetration to a depth of approximately 1 mil below the scale/deposit. The outer layer was iron oxide, while the inner layer (Figure 16) was chromium oxide with notable additions of silicon and sulfur. The sulfides contained iron, manganese, and chromium. The inside surface [Figure 15 (bottom photomicrograph)] contained oxide that was approximately 0.8 mil thick.

The outside surface of the sample in the cooler section (sample 4) also exhibited a two-layer scale/deposit, although it was thinner and present in fewer areas compared to the OD scale/deposit on sample 14. EDX analysis revealed that the elemental makeup of the scale layers was similar to that in sample 14. The degree of internal sulfidation was also lower in sample 4, and the inside surface was free of scale.

$800 \mathrm{HT}$ (Figure 17) - Both $800 \mathrm{HT}$ samples exhibited a two-layer scale/deposit with some minor internal oxidation and sulfidation. The depth of the internal penetration was approximately $1 \mathrm{mil}$ in each sample. The outer scale layer was iron rich and contained embedded fly-ash particles. The inner layer (Figure 18) was predominantly chromium oxide. The sulfides contained iron, manganese, and chromium.

310 modified (Figure 19) - The 310 modified sample in both sections contained a thin, chromium-rich scale with embedded fly-ash particles. No internal oxidation or sulfidation was noted.

HR3C (Figure 19) - For the most part, both HR3C samples exhibited a thin, chromiumrich scale on the outside surface. In a few localized areas (middle photomicrograph) on the hotter section (sample 15), a thicker scale/deposit with subjacent internal oxidation to a depth 
of approximately 1 mil was noted. The outer layer of the scale/deposit was primarily iron oxide and contained fly ash.

NF 709 (Figure 19) - Most areas in both samples contained a thin, chromium-rich scale on the outside surface. One localized area (bottom photomicrograph) in the hotter section (sample 13) exhibited internal oxidation and sulfidation to a depth of approximately 1 mil. The sulfides shown in Figure 20 contained iron, manganese, and chromium.

671 (Figure 21) - Both samples contained a scale/deposit comprised predominantly of the deposit in the outer layer and a thin, chromium-rich oxide on the metal surface. No internal oxidation or sulfidation was evident. The inside surface (which consisted of LSS stainless steel material) contained a 4-mil-thick oxide (bottom photomicrograph) in the hotter section (sample 16) and a 1-mil-thick oxide scale in the cooler section (sample 6). On the basis of the microscopic examination, the large calculated wall loss from the wall thickness measurements for these samples appears to be the result of the internal scaling. The wall loss from the outside surface is estimated to be less than 1 mil.

690 (Figure 22) - Similar to the 671 samples, both 690 samples displayed a thin, chromium-rich oxide on the outside surface. In a few areas in the hotter section (top photomicrograph), internal oxidation on the OD surface was noted to a depth of approximately 1 mil. No sulfidation was detected in either sample. The inside surface (which also consisted of LSS stainless steel material) contained a 2-mil-thick oxide scale (bottom photomicrograph) in the hotter section (sample 17) and a 1-mil-thick scale in the cooler section (sample 7). On the basis of the microscopic examination, the calculated wall loss from the wall thickness measurements for these samples also appears to be the result of the internal scaling. The wall loss from the outside surface is estimated to be less than 1 mil.

$\mathrm{Fe}_{3} \mathrm{AL}$ (Figure 23) - The outside surface of both $\mathrm{Fe}_{3} \mathrm{AL}$ specimens was essentially free of any scale/deposit. Shallow pits (bottom photomicrograph) were noted in isolated areas in the hotter section (sample 18). The material in the pits was predominantly aluminum oxide. Numerous cracks that initiated from the outside surface were evident in both samples. The oxide in the cracks was rich in iron and contained some aluminum.

\section{Wastage Determination}

Wastage is considered the sum total of wall loss (Table 8) and metal rendered ineffective because of internal penetration of corrosive species (e.g., oxides, sulfides). Since only the wastage from the outside surface is of concern, wall loss from oxidation of the inside surface must be discounted. On this basis, the wastage of the specimens determined from 
the macroscopic and microscopic examinations is given in Table 9 and plotted in Figure 24 for the total wastage without the localized attack in the one NF 709, 690, and HR3C samples.

\section{DISCUSSION}

The 4000-hour probe results are the first of three data points being obtained on this project. The 12,000- and 16,000-hour results will be obtained in mid-1997. The wastage in the 4000-hour probe was minimal and, therefore, only limited discussion and conclusions can be made at this time. The analysis of all three probes exposed for longer times will provide a better data base for discussion.

The corrosion mechanisms observed are combined oxidation and sulfidation. The pitting nature in the attack would also indicate that a molten salt, i.e, alkali-iron-trisulfate, may also be operative for at least part of the exposure. Previous $x$-ray diffraction of the corrosion products on the tubes from the boiler has identifed the presence of potassium-iron-trisulfate. The alloys with higher chromium levels have the ability to form a more protective chromium oxide and thus better corrosion resistance to the coal-ash corrosion mechanism.

The silicon and aluminum addition in $85 \mathrm{H}$ and the silicon addition in 253MA do not appear in $\mathbf{4 0 0 0}$ hours to provide any increased corrosion resistance. The tantalum addition in 310 modified, on the other hand, is very beneficial in reducing the corrosion.

The fuels burned at TVA Gallatin have a composition which results in a Borio Index of 3. This index is a measure of aggressiveness from the sodium and potassium, and that number implies a moderate to highly aggressive fuel.

The effect of temeprature was not conclusive from the data of this program, possibly because of the low wastage measured. Previous programs have shown that the temperature for maximum corrosion is a function of the alloy composition. Alloys with lower corrosion resistance usually have a higher wasage rate at a lower temperature than the alloys with higher corrosion resistance. This temperature effect will be better evaluated on the probes with longer exposure times.

\section{CONCLUSIONS}

The air-cooled retractable corrosion probes are working successfully and are providing exposure of each of the nine alloys to two different temperatures. The wastage measurements from the 4000 -hour exposure indicate a wastage for 347 of about 2.5 mils. The field 
Table 9. Maximum Total Wastage of Specimens

\begin{tabular}{|c|c|c|c|c|c|}
\hline Sample & Material & $\begin{array}{l}\text { Total } \\
\text { Wall Loss } \\
\text { (mils) }\end{array}$ & $\begin{array}{l}\text { ID } \\
\text { Wall Loss From } \\
\text { Oxidation (mils) }\end{array}$ & $\begin{array}{l}\text { OD Penetration } \\
\text { (mils) }\end{array}$ & $\begin{array}{c}\text { Total Wastage } \\
\text { (mils) }\end{array}$ \\
\hline 1 & $85 \mathrm{H}$ & 0 & 0 & 2.5 & 2.5 \\
\hline 2 & 347 & 2.7 & 0.5 & 0.5 & 2.7 \\
\hline 3 & NF 709 & 0 & 0 & 0.5 & 0.5 \\
\hline 4 & 253 MA & 1.9 & 0 & 0.5 & 2.4 \\
\hline 5 & HR3C & 0.9 & 0 & 0 & 0.3 \\
\hline 6 & 671 & 4.0 & 1.0 & 0 & $<1.0^{*}$ \\
\hline 7 & 690 & 1.1 & 1.0 & 0 & $<1.0^{*}$ \\
\hline 8 & $\mathrm{Fe}_{3} \mathrm{Al}$ & 0 & 0 & 0 & 0 \\
\hline 9 & $310 t$ & 0 & 0 & 0 & 0 \\
\hline 10 & $800 \mathrm{HT}$ & 0.5 & 0 & 1.0 & 1.5 \\
\hline 11 & $85 \mathrm{H}$ & 0.5 & 0 & 2.5 & 3.0 \\
\hline 12 & 347 & 2.0 & 0.5 & 0.5 & 2.0 \\
\hline 13 & NF 709 & 1.6 & 0 & $(1.0) \S$ & $1.6(2.6) 5$ \\
\hline 14 & $253 \mathrm{MA}$ & 1.2 & 0.8 & 1.0 & 1.4 \\
\hline 15 & HR3C & 0.8 & 0 & $(1.0) \S$ & $0.8(1.8) \xi$ \\
\hline 16 & 671 & 9.7 & 4.0 & 0 & $<1.0^{*}$ \\
\hline 17 & 690 & 4.9 & 2.0 & $(1.0) 5$ & $<1.0^{*}(1.0) \S$ \\
\hline 18 & $\mathrm{Fe}_{3} \mathrm{Al}$ & 0 & 0 & 0 & 0 \\
\hline 19 & $310 t$ & 0.1 & 0 & 0 & 0.1 \\
\hline 20 & $800 \mathrm{HT}$ & 0.5 & 0 & 1.0 & 1.5 \\
\hline
\end{tabular}

measurements indicate the same benefit of chromium in providing corrosion resistance (i.e., the higher the chromium level, the lower the corrosion) as the previous Phase I laboratory testing. The exception to this is that the iron aluminide with only 5-percent chromium showed no evidence of measurable corrosion. Also, the 310 modified with tantalum performed better than the same 25-percent chromium HR3C with niobium. The data from the 
future 12,000- and 16,000-hour probes will further evaluate whether these preliminary findings are true. The mode of attack for most of the samples is oxidation and sulfidation. All of these alloys have considerable coal ash corrosion resistance, and the general metal wastage by a fluxing action is therefore minimal.

Future metallographic and corrosion deposit analyses will verify the wastage rates and corrosive attack mechanisms (i.e., coal ash, erosion-assisted oxidation, etc.).

\section{REFERENCES}

1. W. Nelson and C. Cain, Jr., "Corrosion of Superheaters and Reheaters of PulverizedCoal-Fired Boilers," Transactions of the ASME, Journal of Engineering for Power, July 1960, pp. 194-204.

2. W. T. Reid, "Formation of Alkali Iron Trisulphates and Other Compounds Causing Corrosion in Boilers and Gas Turbines," Project Review July 1, 1966-June 30, 1968, prepared by Battelle Memorial Institute, Columbus, OH, June 1968.

3. W. T. Reid, External Corrosion and Deposits: Boilers and Gas Turbines, American Elsevier Publishing Company, New York, 1974.

4. G. J. Hills, "Corrosion of Metals by Molten Salts," Proceedings of the Marchwood Conference: Mechanism of Corrosion by Fuel Impurities, Johnson and Littler, eds., Butterworths, London, 1963.

5. J. L. Blough, G. J. Stanko, M. Krawchuk, W. Wolowodiuk, and W. Bakker, "In Situ Coal Ash Corrosion Testing for 2 Years at Three Utilities, "International EPRI Conference on Improved Technology for Fossil Power Plants New and Retrofit Applications, Washington, DC, March 1-3, 1993.

6. I. M. Rehn, "Fireside Corrosion of Superheater and Reheater Tubes," Palo Alto, CA: Electric Power Research Institute, 1980. CS-1653.

7. I. M. Rehn, "Fireside Corrosion of Superheater Alloys for Advanced Cycle Steam Plants," Palo Alto, CA: Electric Power Research Institute, 1987. EPRI 5195.

8. S. Van Weele and J. L. Blough, "Literature Search Update-Fireside Corrosion Testing of Candidate Superheater Tube Alloys, Coatings, and Claddings," Livingston, NJ: Foster Wheeler Development Corporation, September 1990. FWC/FWDC/TR-90-11.

9. W. Wolowodiuk, S. Kihara, and K. Nakagawa, "Laboratory Coal Ash Corrosion Tests," Palo Alto, CA: Electric Power Research Institute, July 1989. GS-6449.

10. S. Van Weele and J. L. Blough, "Fireside Corrosion Testing of Candidate Superheater, Tube Alloys, Coatings, and Claddings," Livingston, NJ: Foster Wheeler Development Corporation, August 1991. ORNL/SUB/89-SA187/02. 
11. S. Kihara, K. Nakagawa, A. Ohtomo, H. Aoki, and S. Ando, "Simulating Test Results for Fireside Corrosion of Superheater \& Reheater Tubes Operating at Advanced Steam Conditions in Coal-Fired Boilers, High Temperature Corrosion in Energy Systems, TMS/AIME, M. F. Rothman, ed., 1984, pp. 361-376.

12. W. Wolowodiuk, et al., "Coal-Ash Corrosion Investigations," Proceedings of the First International Conference on Improved Coal-Fired Power Plants. Palo Alto, CA: Electric Power Research Institute, November 1986.

13. J. L. Blough, M. T. Krawchuk, G. J. Stanko, and W. Wolowodiuk, "Superheater Corrosion Field Test Results," Palo Alto, CA: Electric Power Research Institute, November 1993. TR-103438.

14. J. L. Blough and W. T. Bakker, "Measurement of Superheater Corrosion Caused by Molten Alkali Sulfates," First International Conference on Heat-Resistant Materials, to be presented at the ASM International, Lake Geneva, WI, September 22-26, 1991.

15. T. Hammond, W. Wolowodiuk, J. L. Blough, J. Brooks, "Replacement of Reheater at TVA's Gallatin Station Unit 2," presented at the Third International Conference on Improved Coal-Fired Power Plants (ICPP), San Francisco, April 1991.

16. R. W. Borio and R. P. Hensel, "Coal-Ash Composition as Related to High-Temperature Fireside Corrosion and Sulfur-Oxides Emission Control," Transactions of the ASME, Journal of Engineering for Power, Vol. 94, 1972, pp. 142-148. 


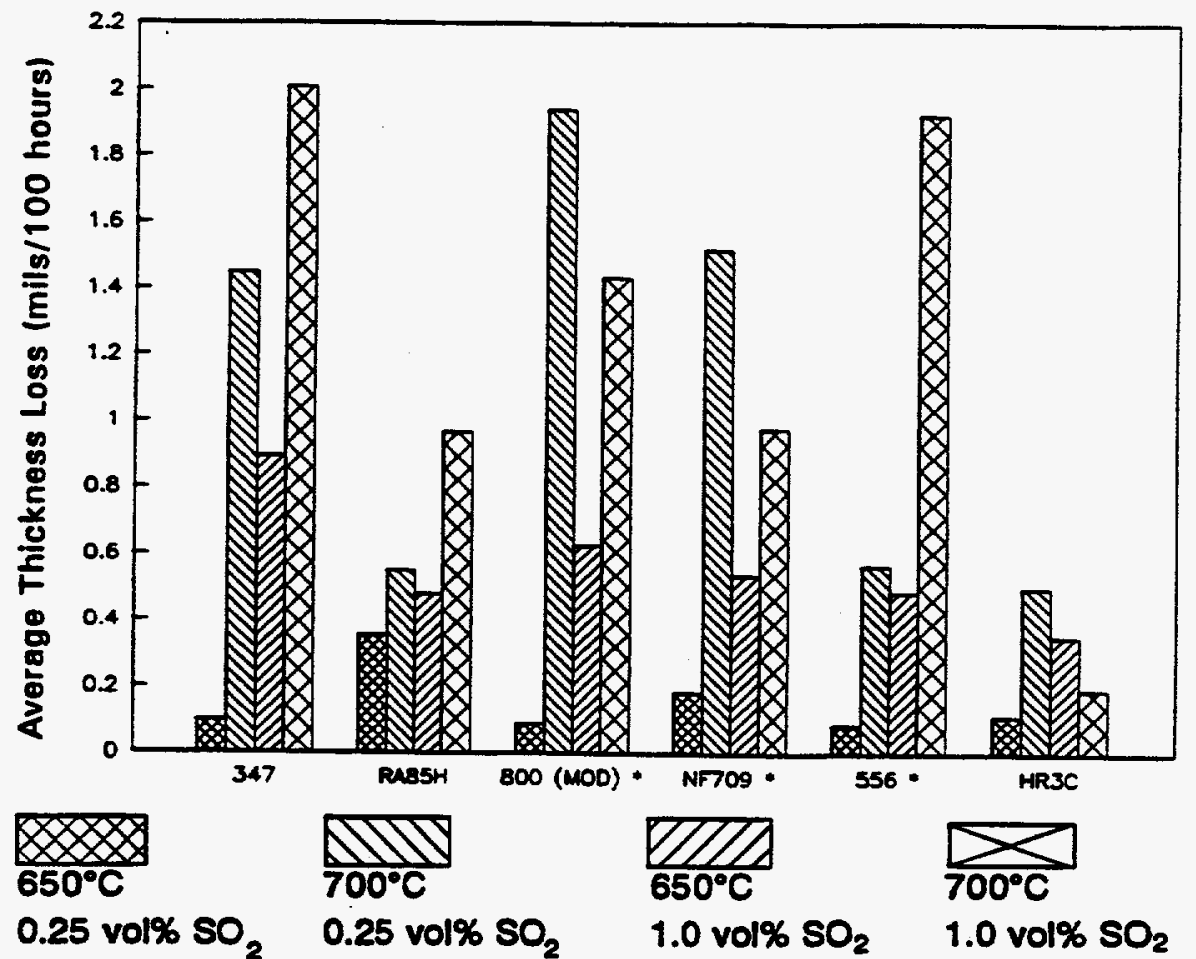

Fig. 1. Average thickness loss rate of alloys containing 14- to 30-percent chromium. (Alloys marked with an asterisk contain between 1-and 4-percent molybdenum.)

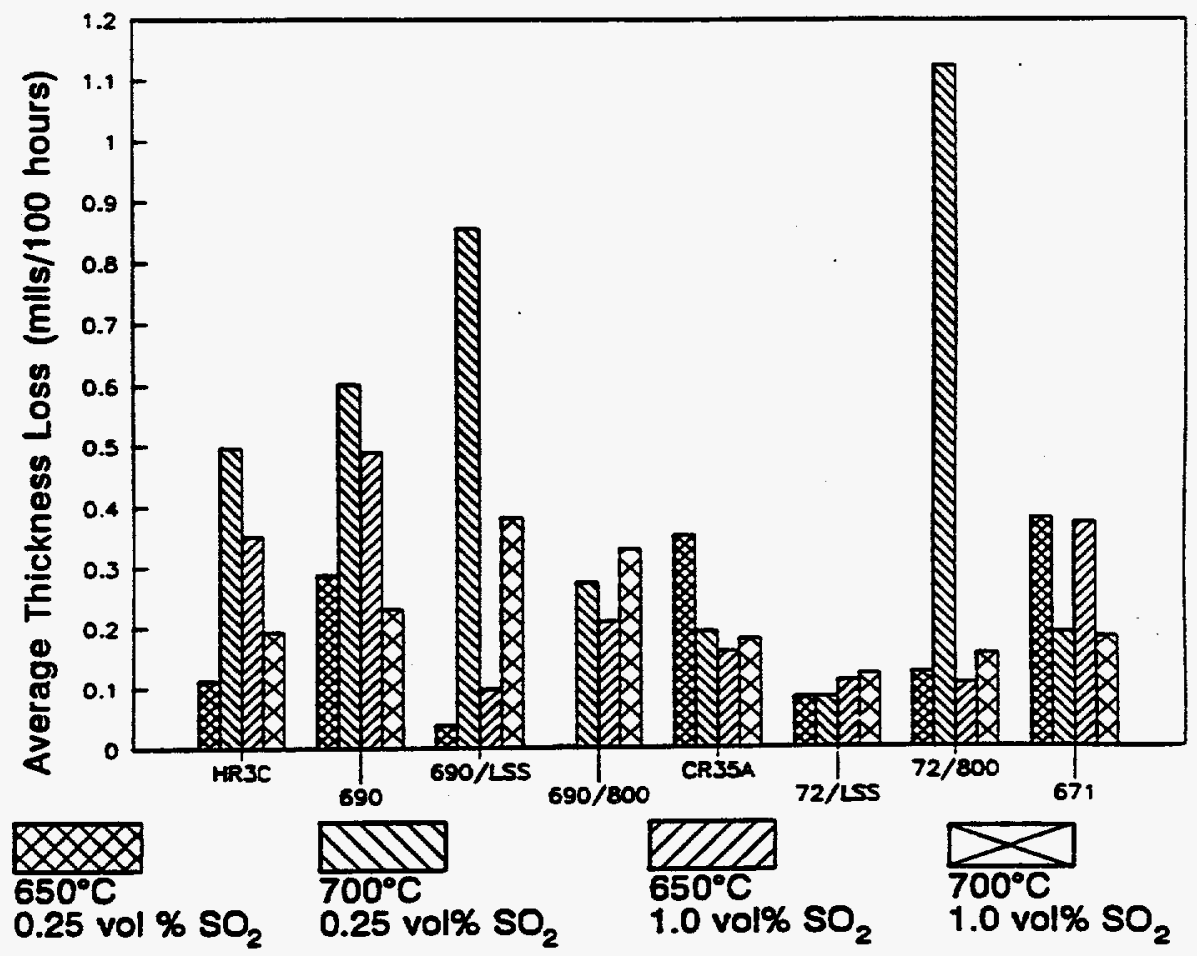

Fig. 2. Average thickness loss rates of various monolithic alloys and claddings coated with ash containing $10 \mathrm{wt} \%$ alkali sulfates and exposed for 800 hours 


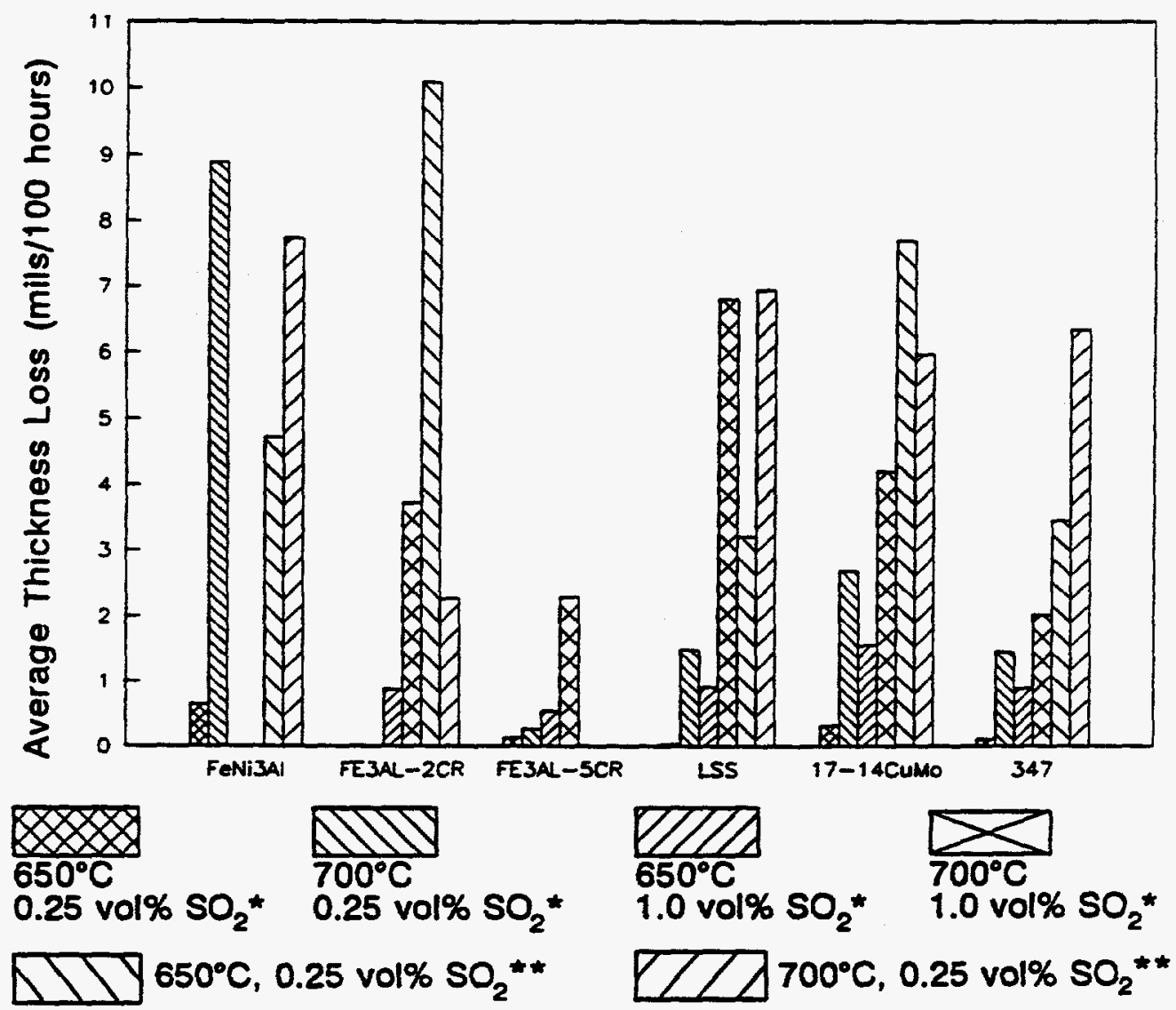

Fig. 3. Average thickness loss rates of three intermetallic aluminides and two stainless steels exposed to a variety of environments. $i^{*}=$ low sulfate ash, ${ }^{*}=$ high sulfate ash) 


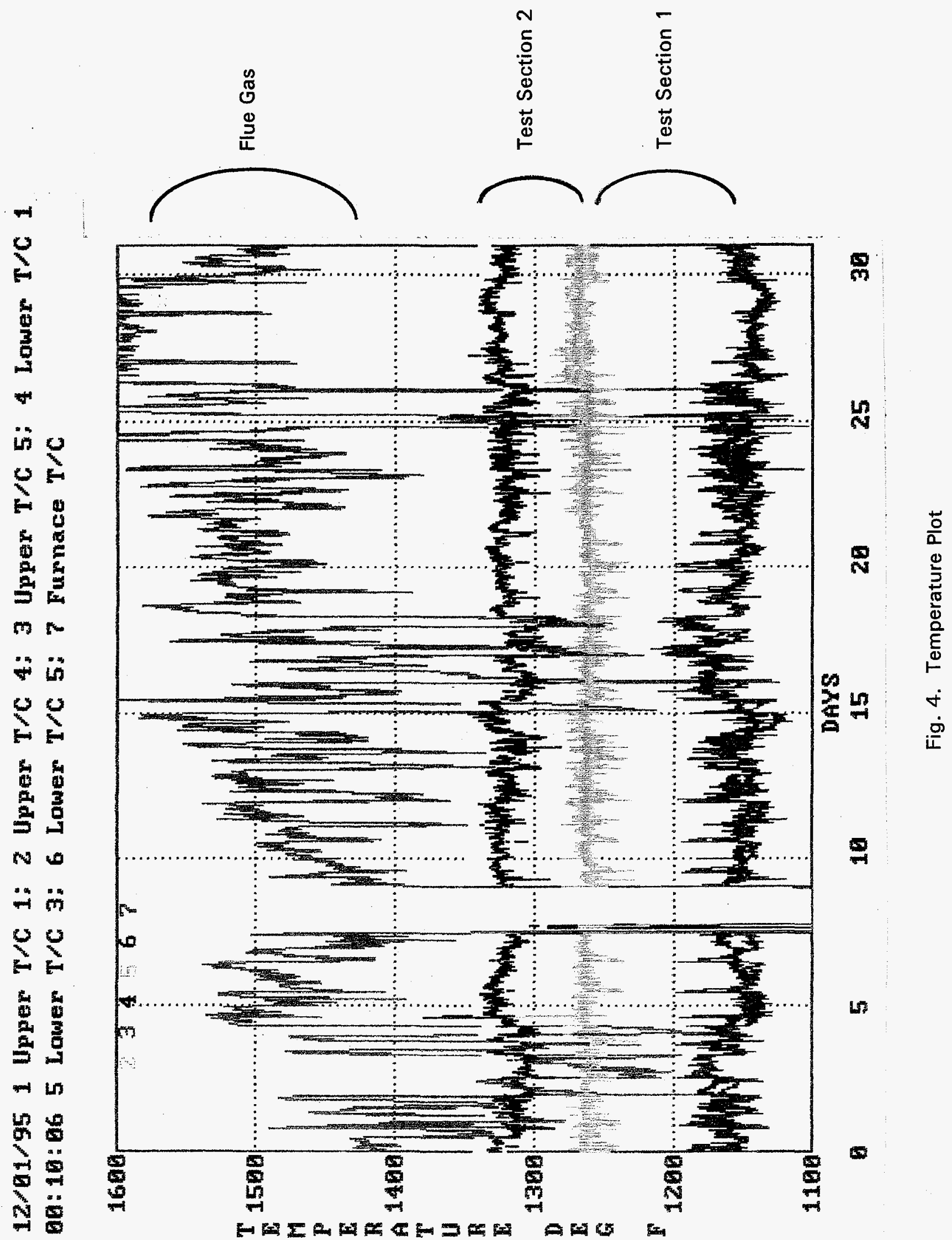




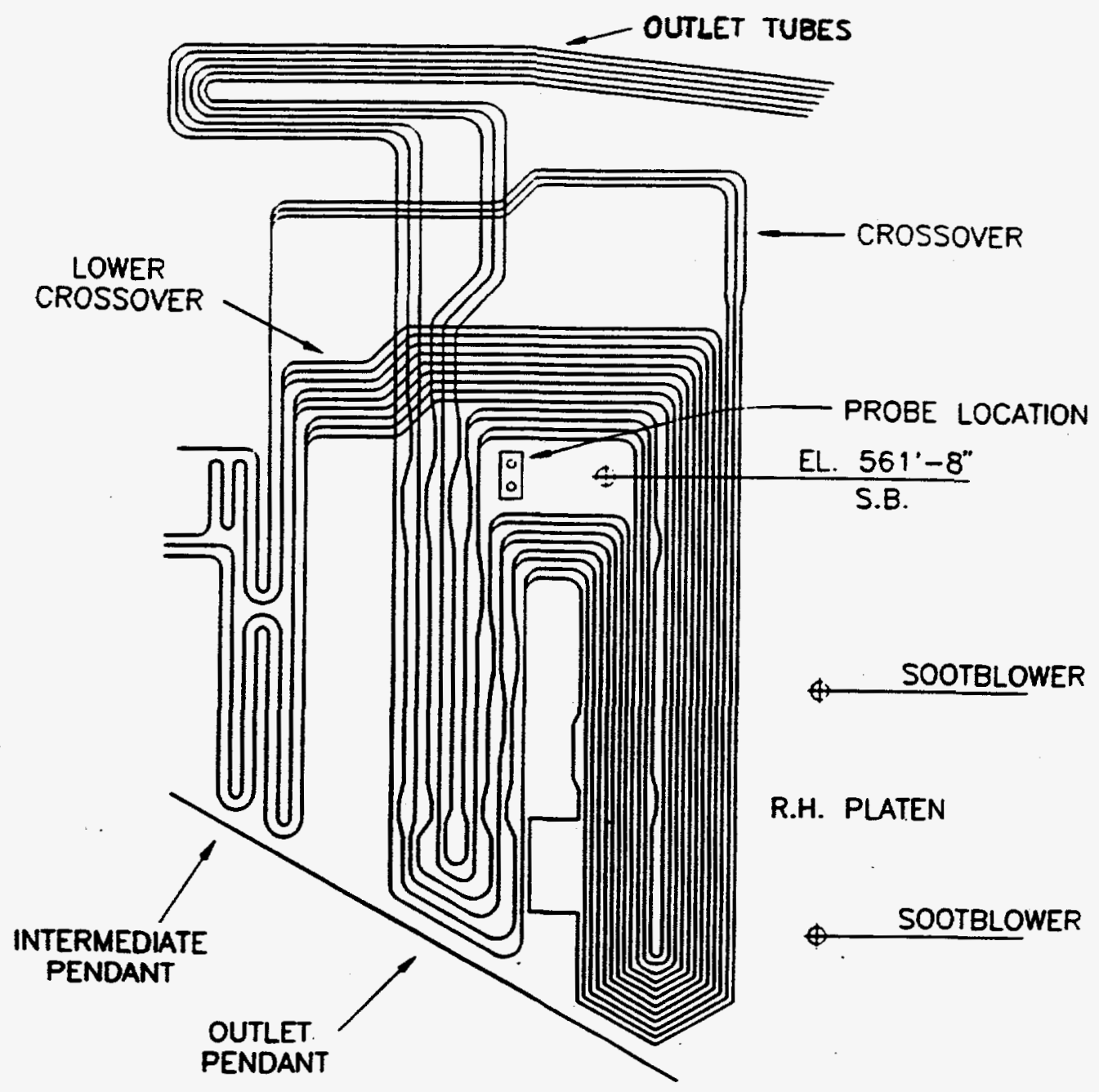

Fig. 5. Side elevation of reheater at TVA Gallatin unit 2 

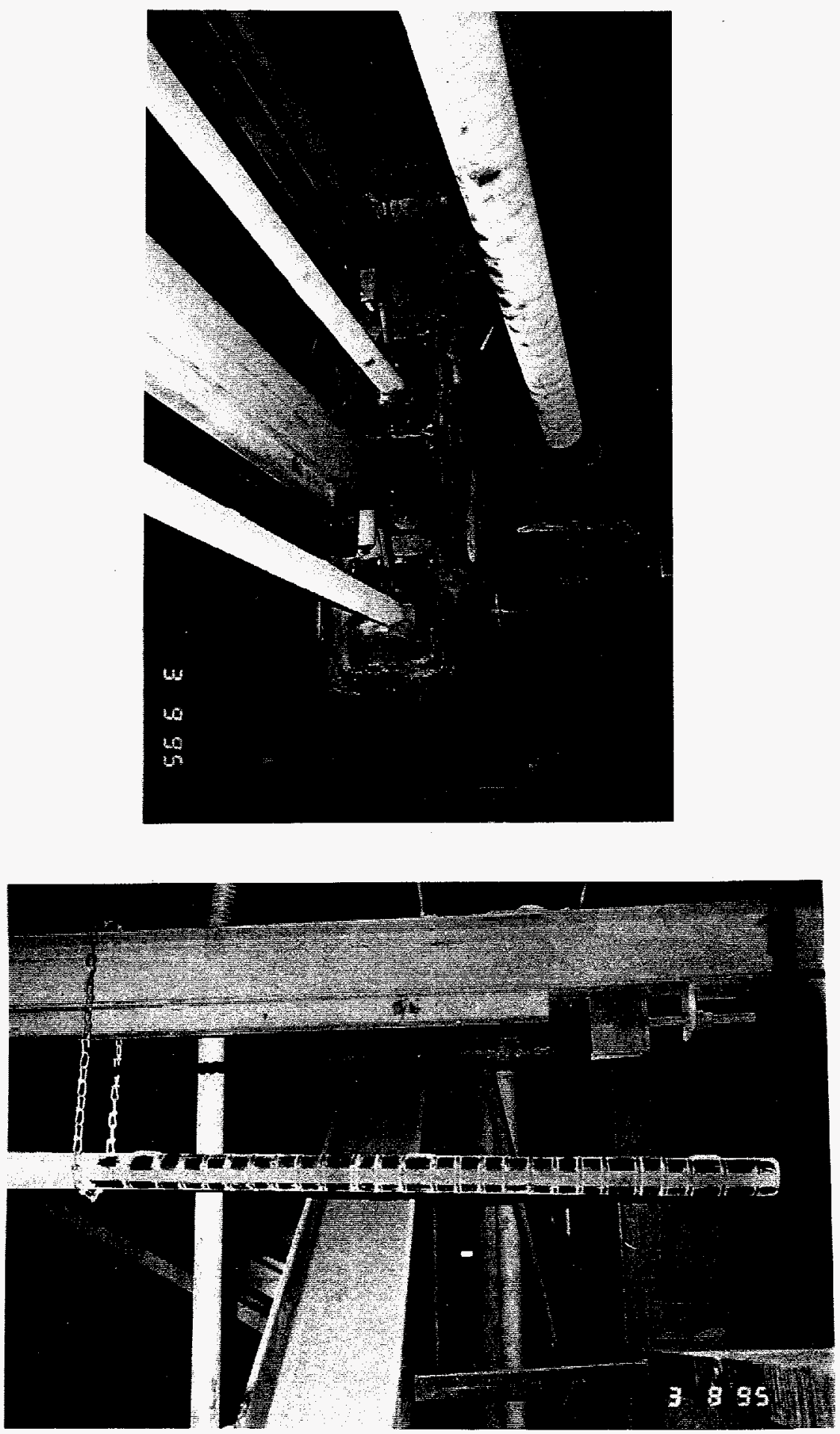

Fig. 6. The two retracted probes on the left and the soot blower on the right are shown in the top photograph. The bottom photograph shows the cleaned probe for ultrasonic thickness measurements. 


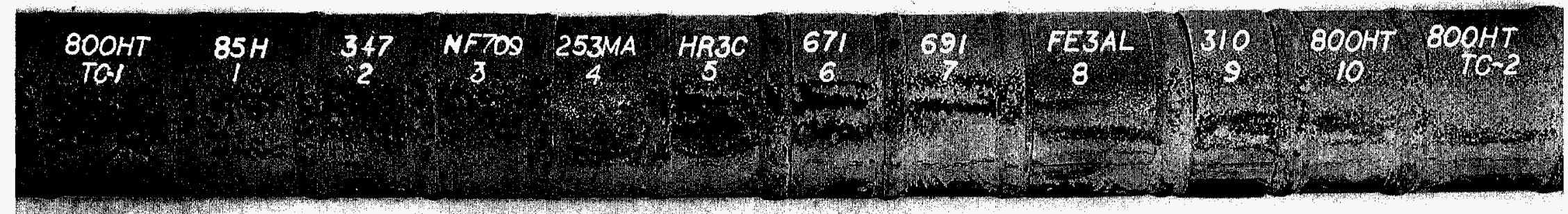

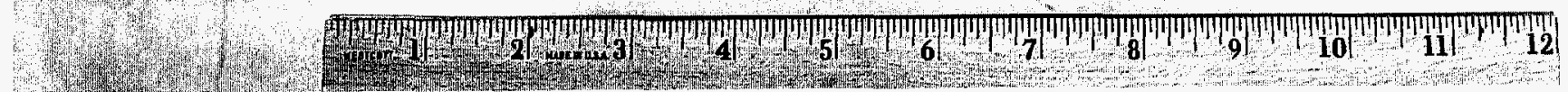

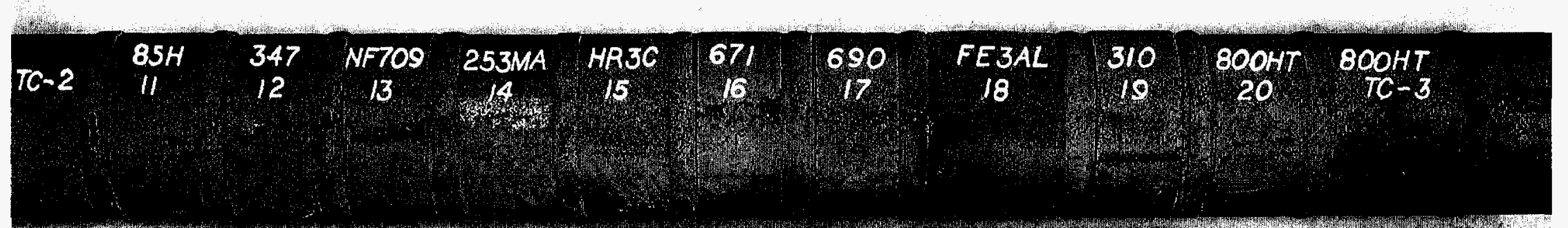

H. .1.7.

Fig. 7. Shown are the probe samples after removal from the probe support pipe. The fireside half of the samples and the rings with the thermocouples are shown. 


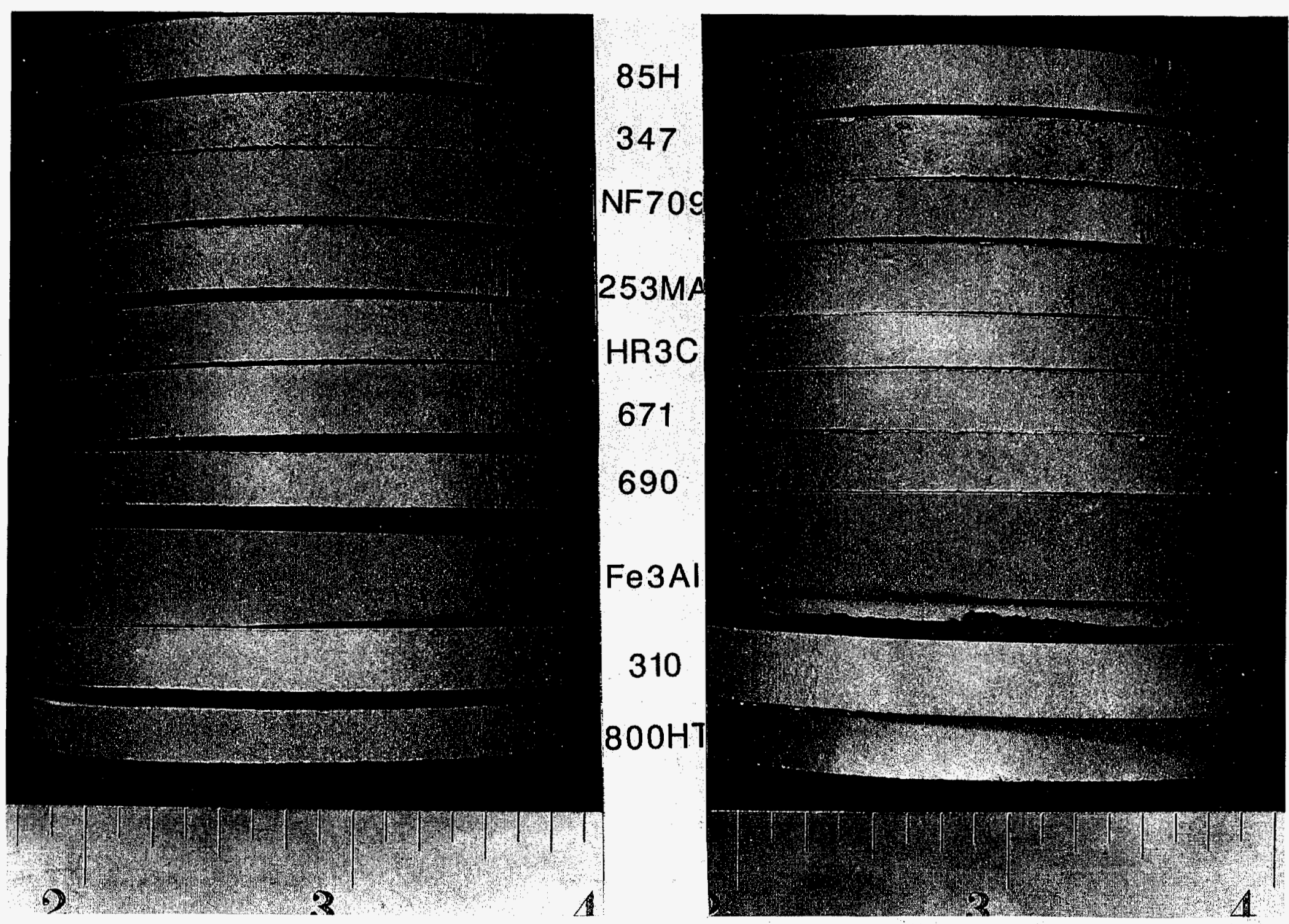

Fig. 8. The grit-blasted rights are oriented with the 135-deg location at the top. The cooler set of samples is on the left. 


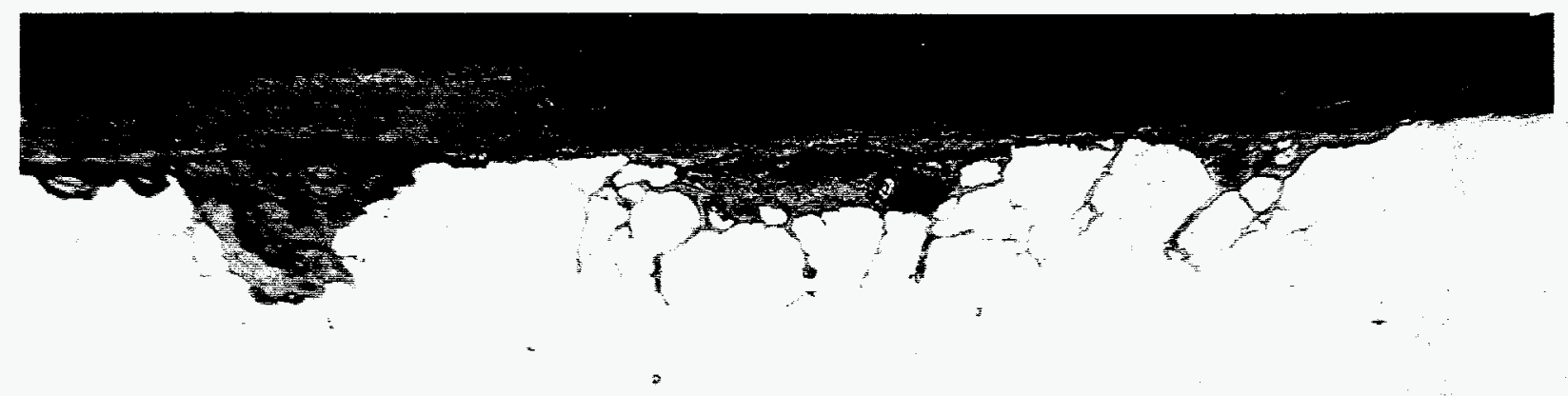

$85 \mathrm{H}-11$

1 mil
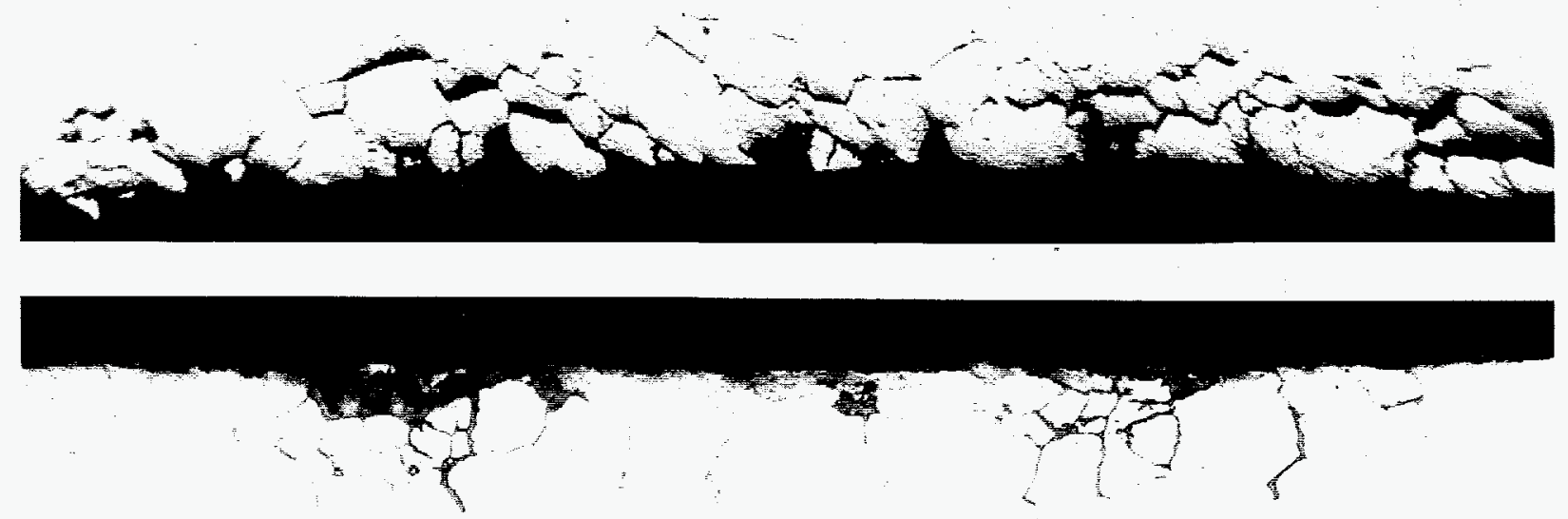

$85 \mathrm{H}-1$
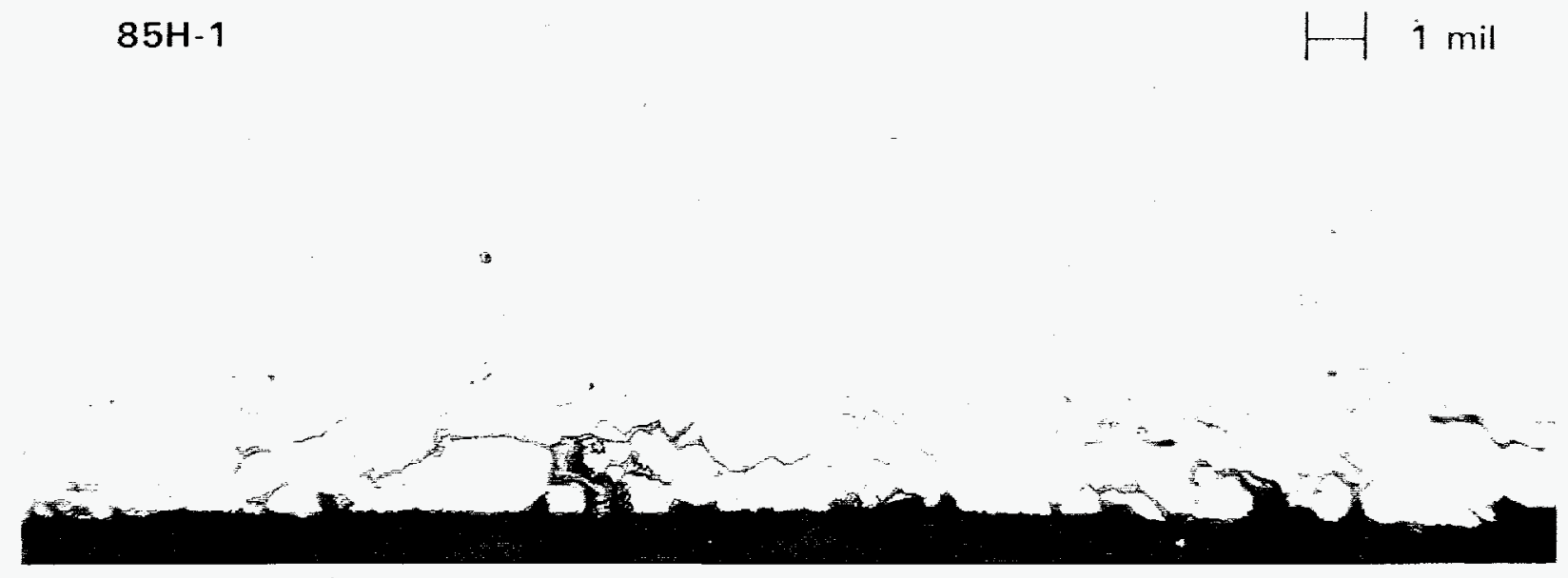

Fig. 9. The intergranular attack on the $O D$ top and $I D$ bottom of each pair of photomicrographs is shown for samples $85 \mathrm{H}-1$ and $85 \mathrm{H}-11$. 

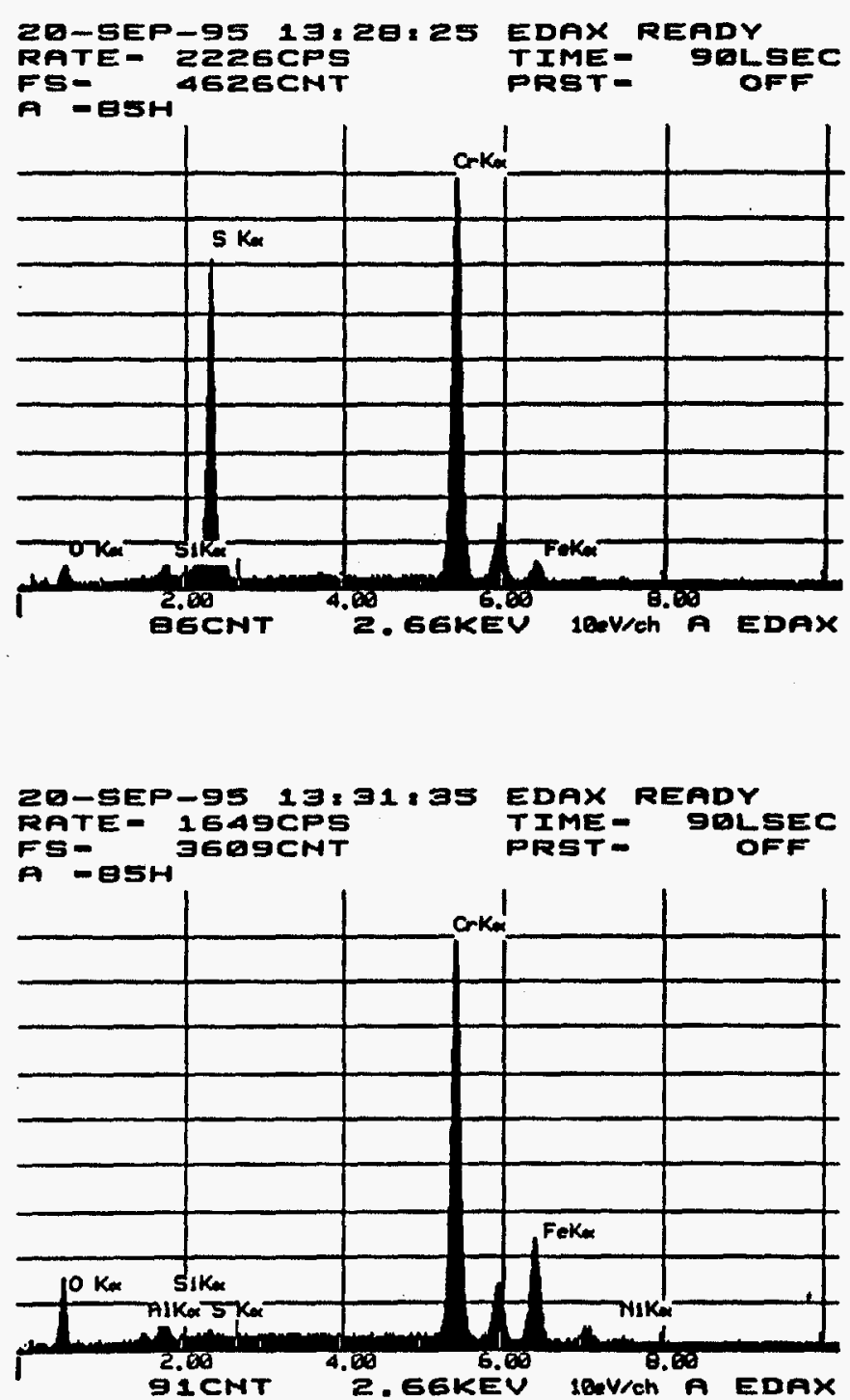

Fig. 10. Shown are EDX spectrums of subsurface chromium sulfides (top) and oxides (bottom) in sample $85 \mathrm{H}-1$ of Figure 9.
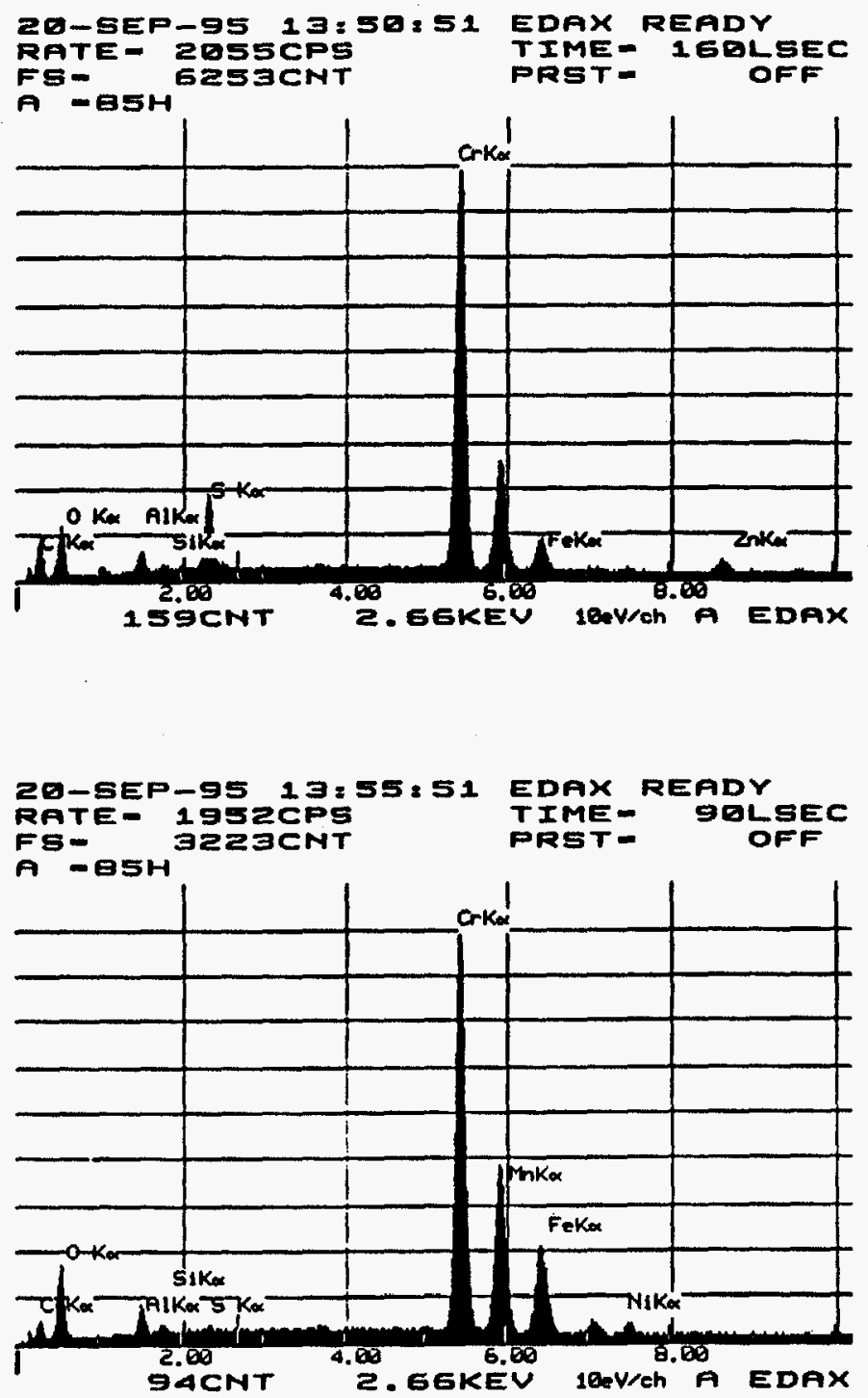

Fig. 11. A few grain boundaries in sample $85 \mathrm{H}-11$ of Figure 9 show the top spectrum but most exhibit the bottom spectrum. 

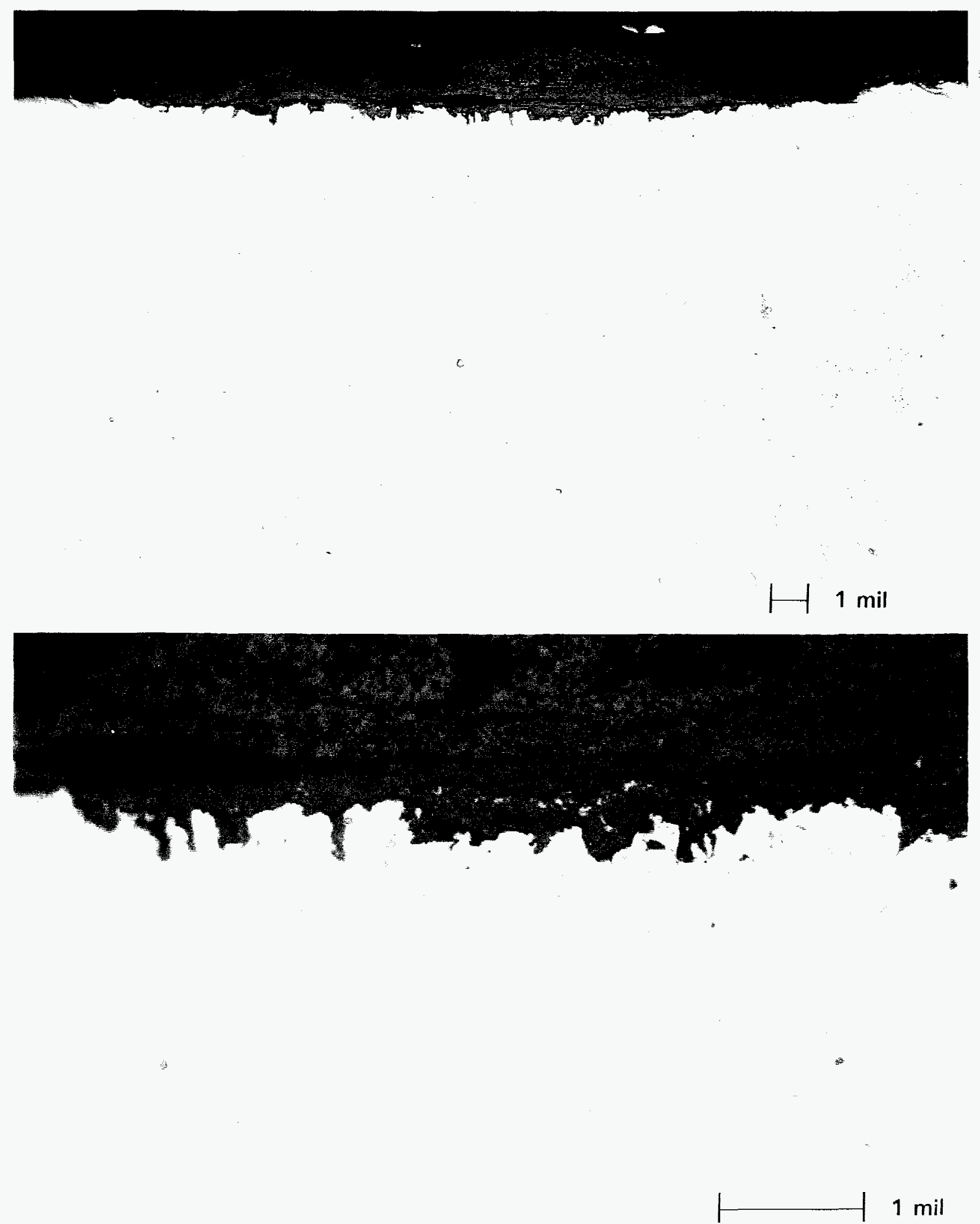

Fig. 12. The slight intergranular penetration at low and high magnification is shown for the 347-2 sample. 


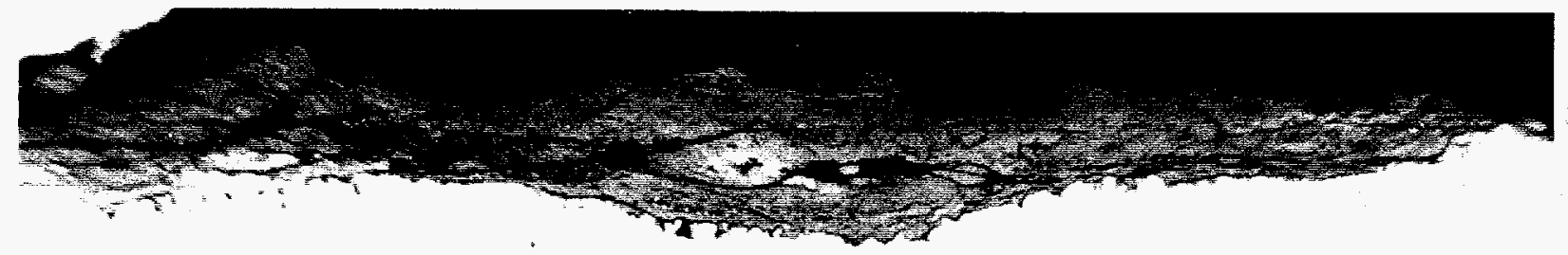

$1 \mathrm{mil}$
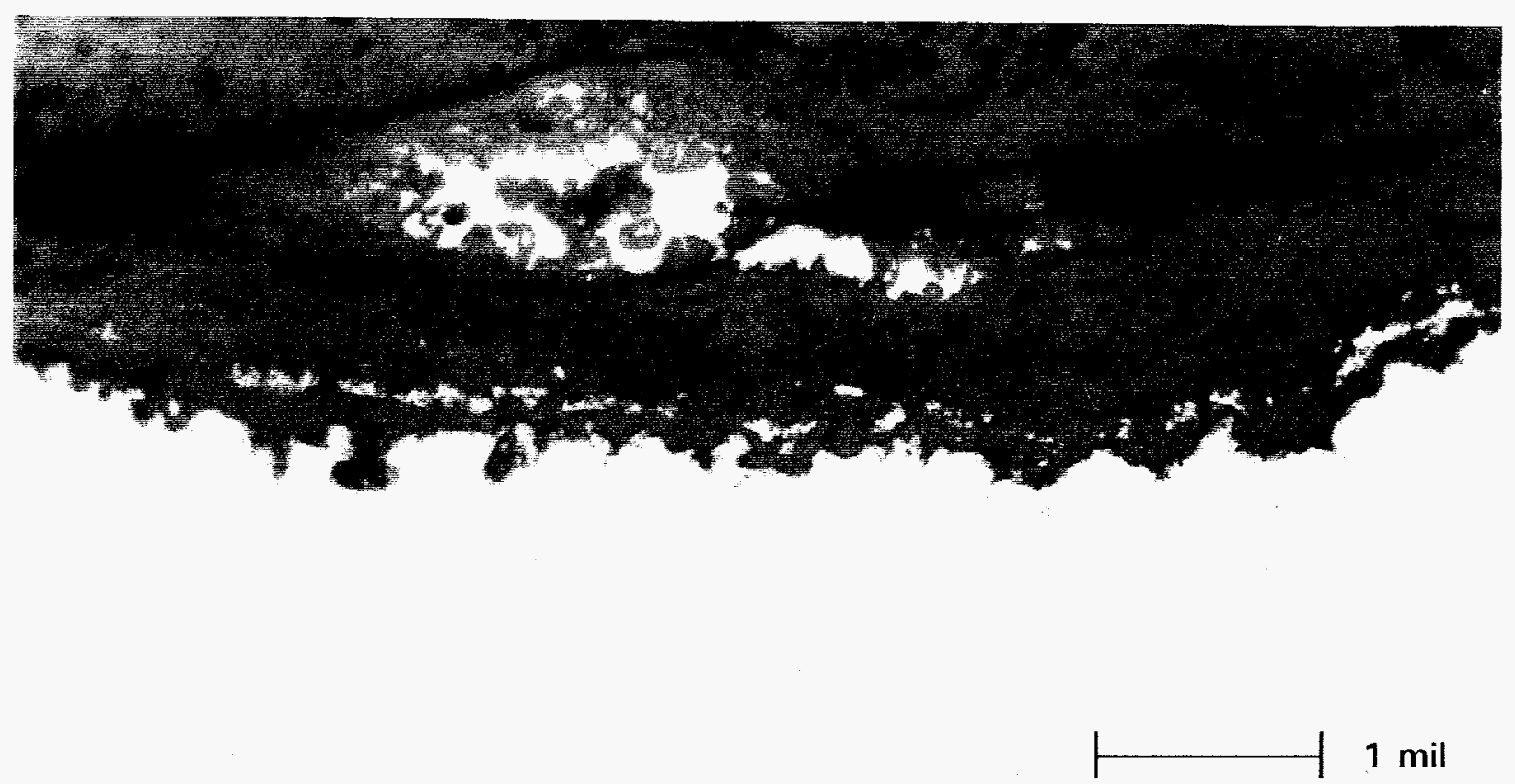

s.

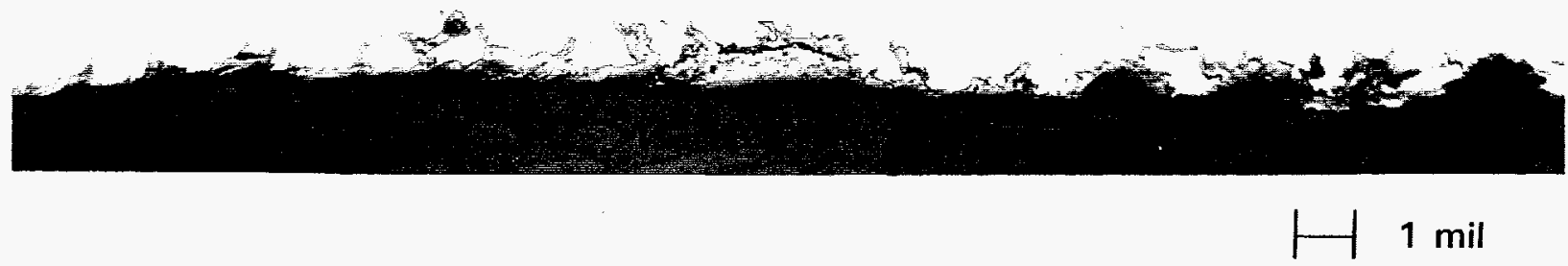

Fig. 13. The general corrosion on the $O D$ and slight intergranular oxidation of the $I D$ of the 347-12 sample is shown. 

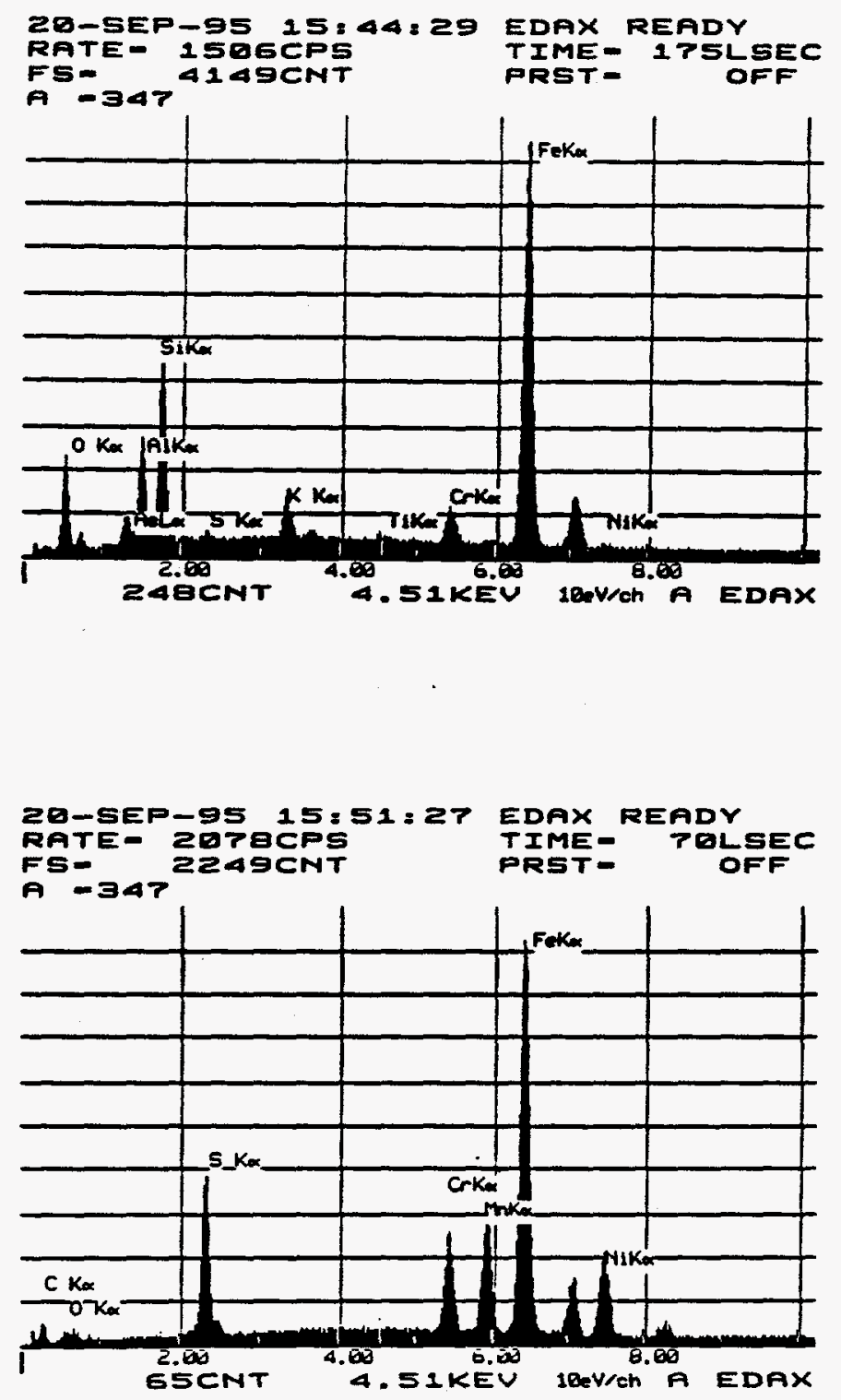

Fig. 14. The outer layer of scale/deposit in sample 347-12 in Figure 13 exhibited the top spectrum. The subsurface sulfides in that sample are shown in the bottom spectrum. 

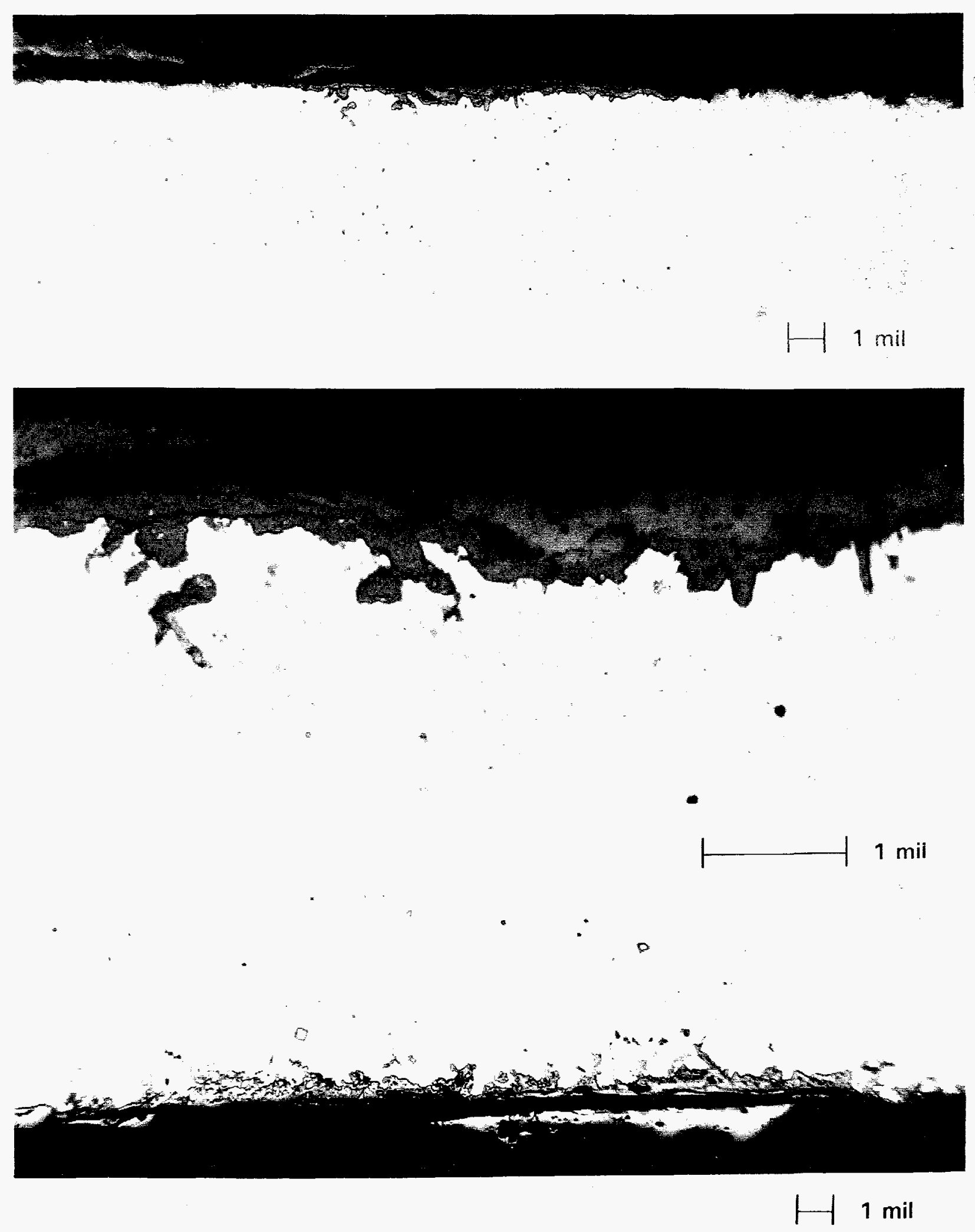

Fig. 15. Corrosion on the OD and intergranular oxidation on the ID of 253MA-14 are shown. 

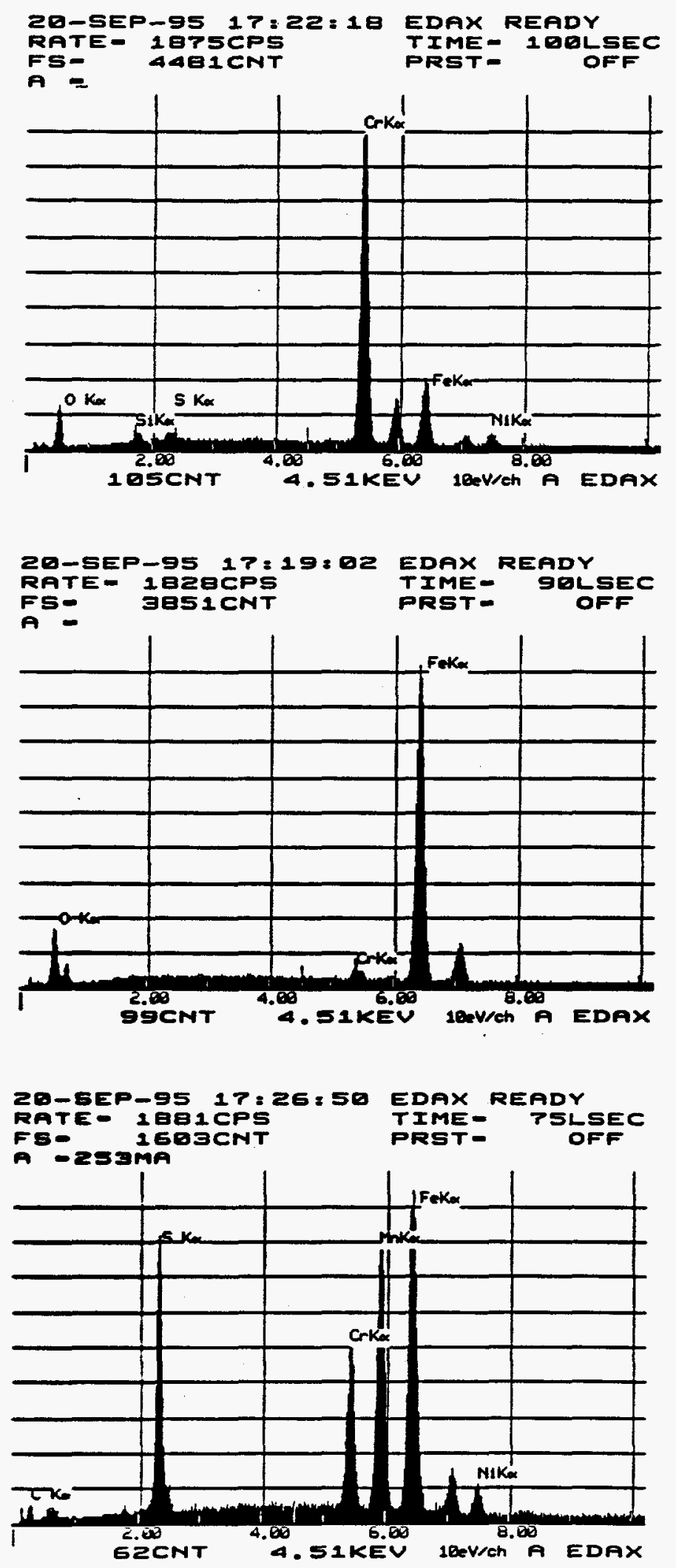

Fig. 16. The spectrums of the outer layer, inner layer, and subsurface sulfides are shown in the top, middle, and bottom spectrums respectively for 253MA-14 in Figure 15. 

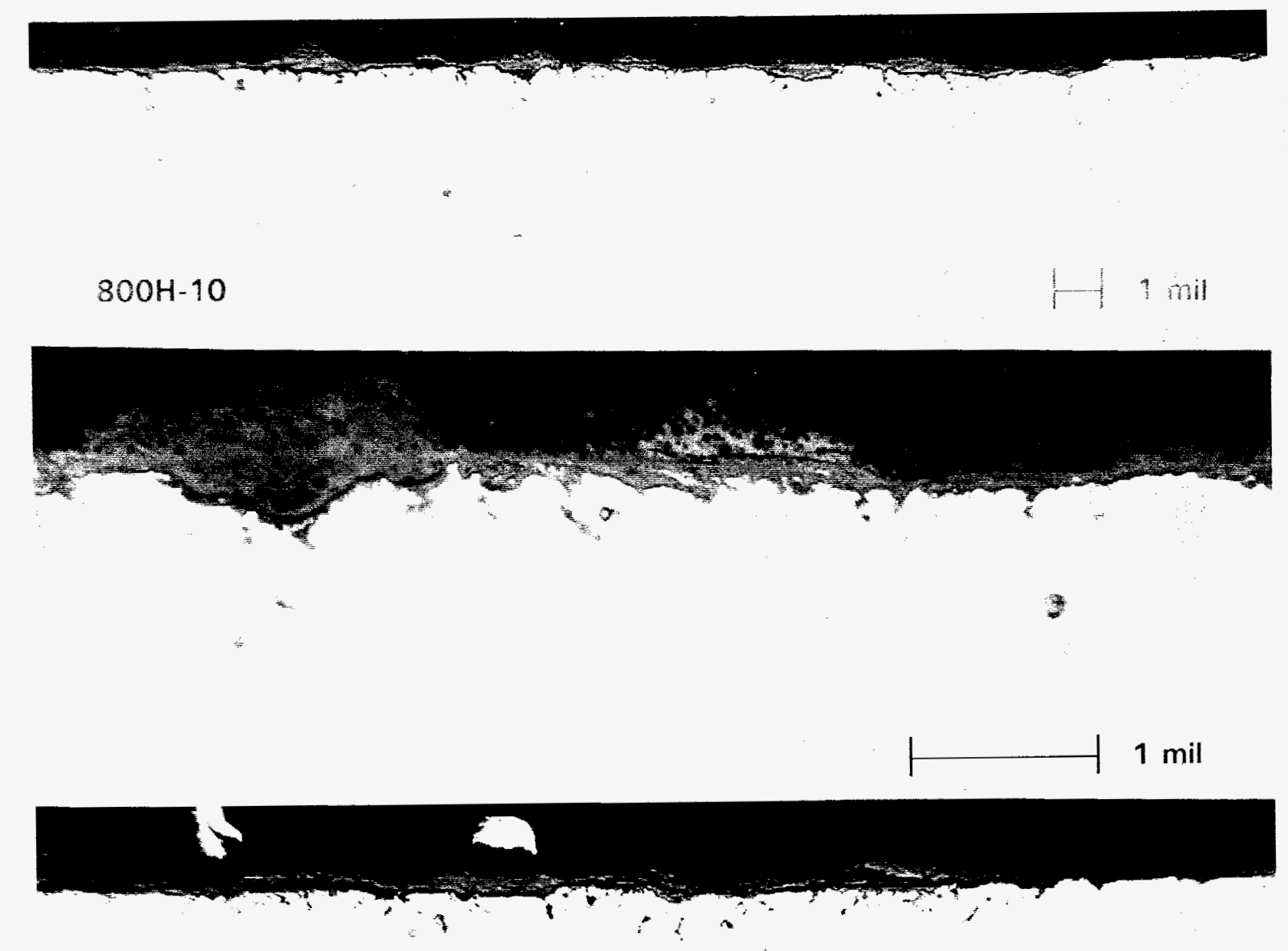

$800 \mathrm{H}-20$

$1 \mathrm{mil}$

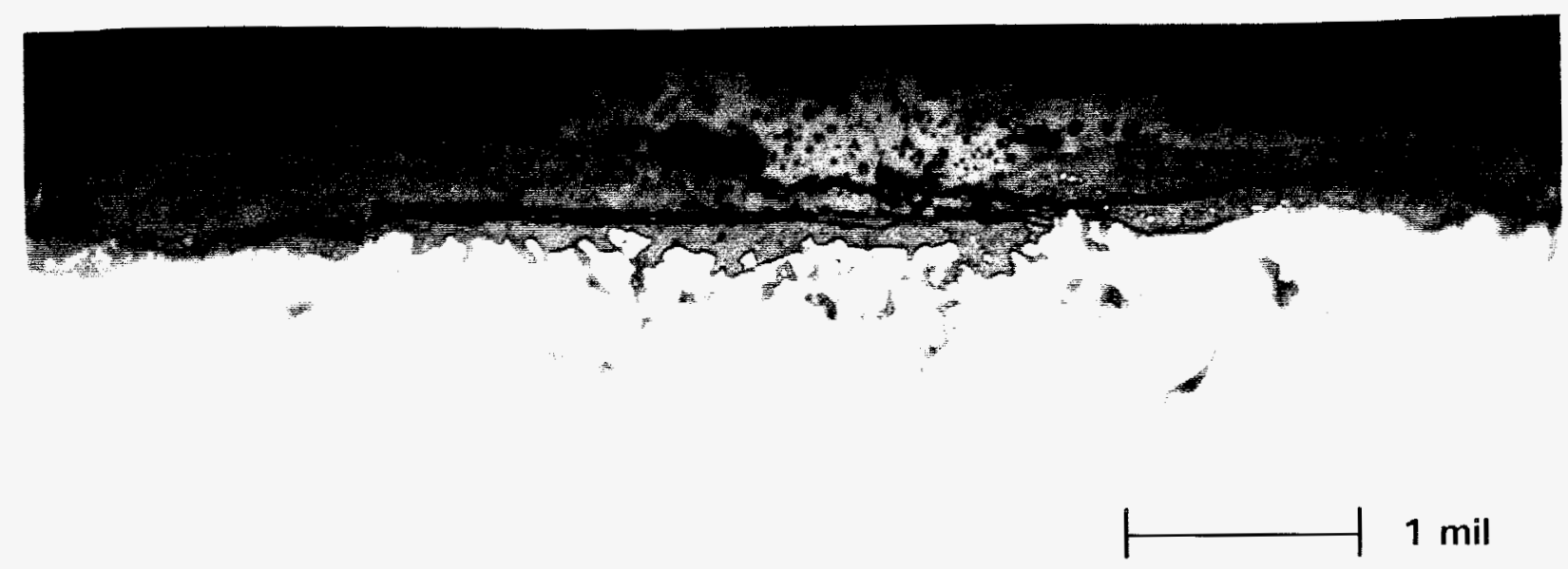

Fig. 17. Pitting and intergranular attack on the $O D$ from the $800 \mathrm{H}-10$ and 20 samples are shown. 

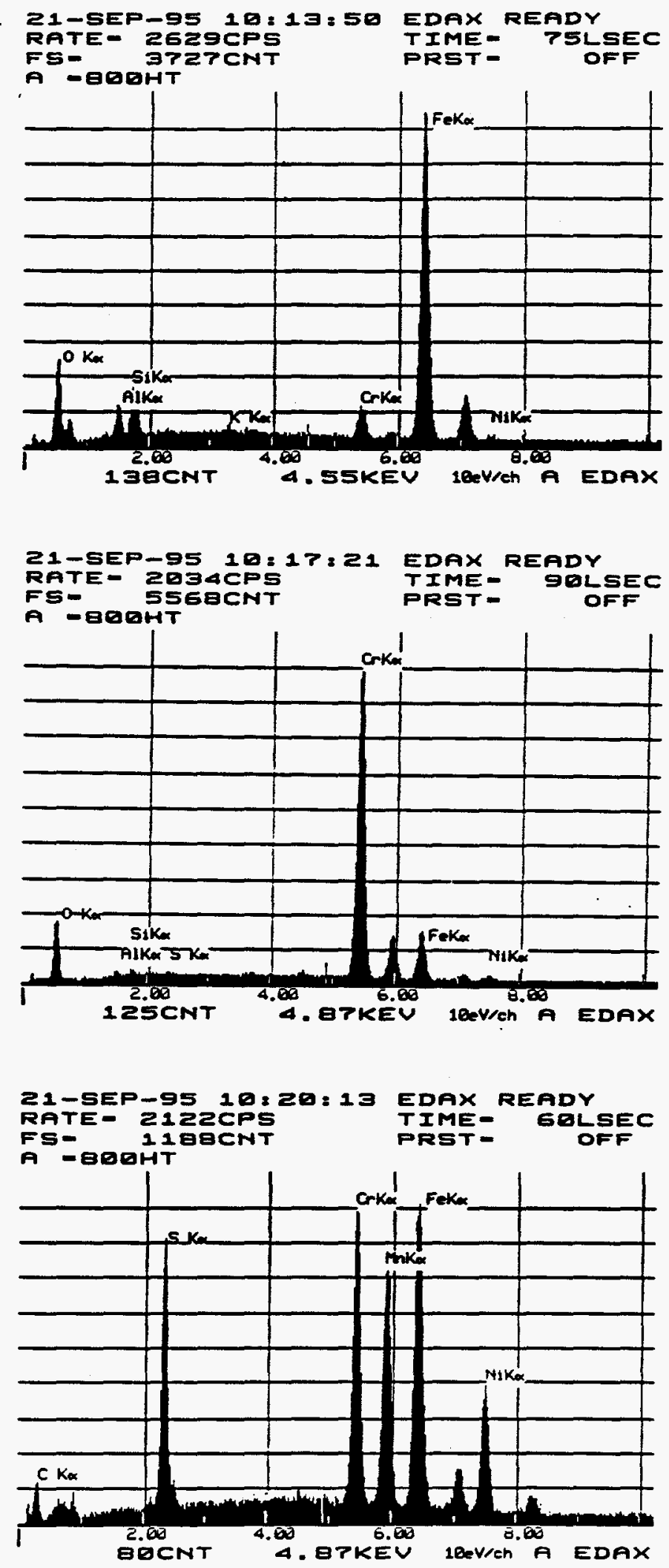

Fig. 18. The spectrums of the outer layer, inner layer, and subsurface sulfides are shown in the top, middle, and bottom spectrums respectively for $800 \mathrm{HT}$ in Figure 17. 


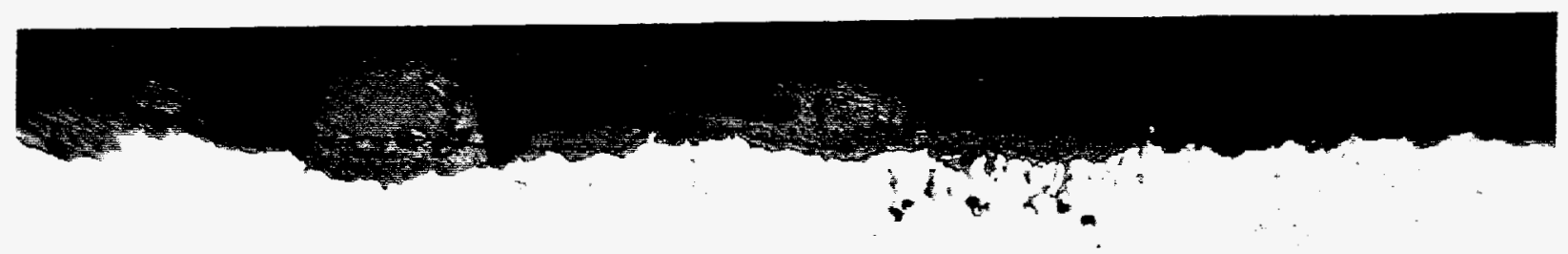

HR3C

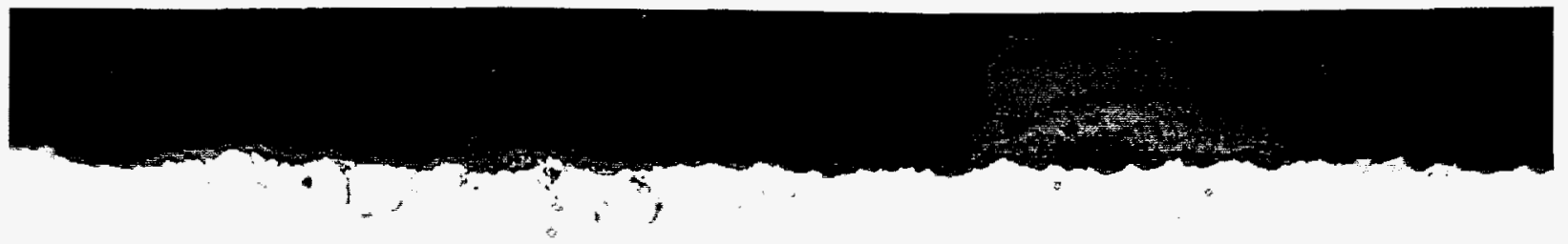

NF709

Fig. 19. Alloys 310 modified, HR3C, and NF 709 are compared. The 310 modified showed the least attack. 

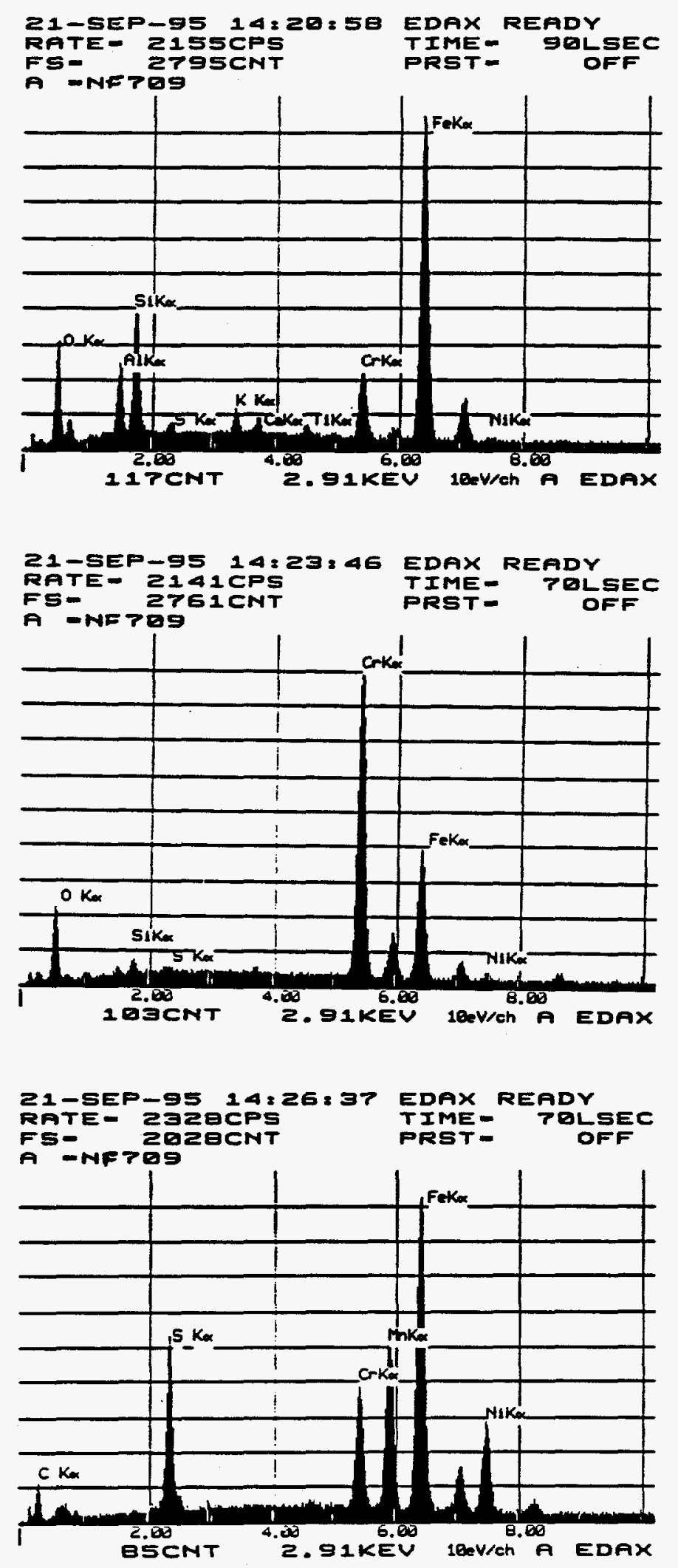

Fig. 20. The spectrums of the outer layer, inner layer, and subsurface sulfides are shown in the top, middle, and bottom spectrums respectively for NF 709 in Figure 19. 

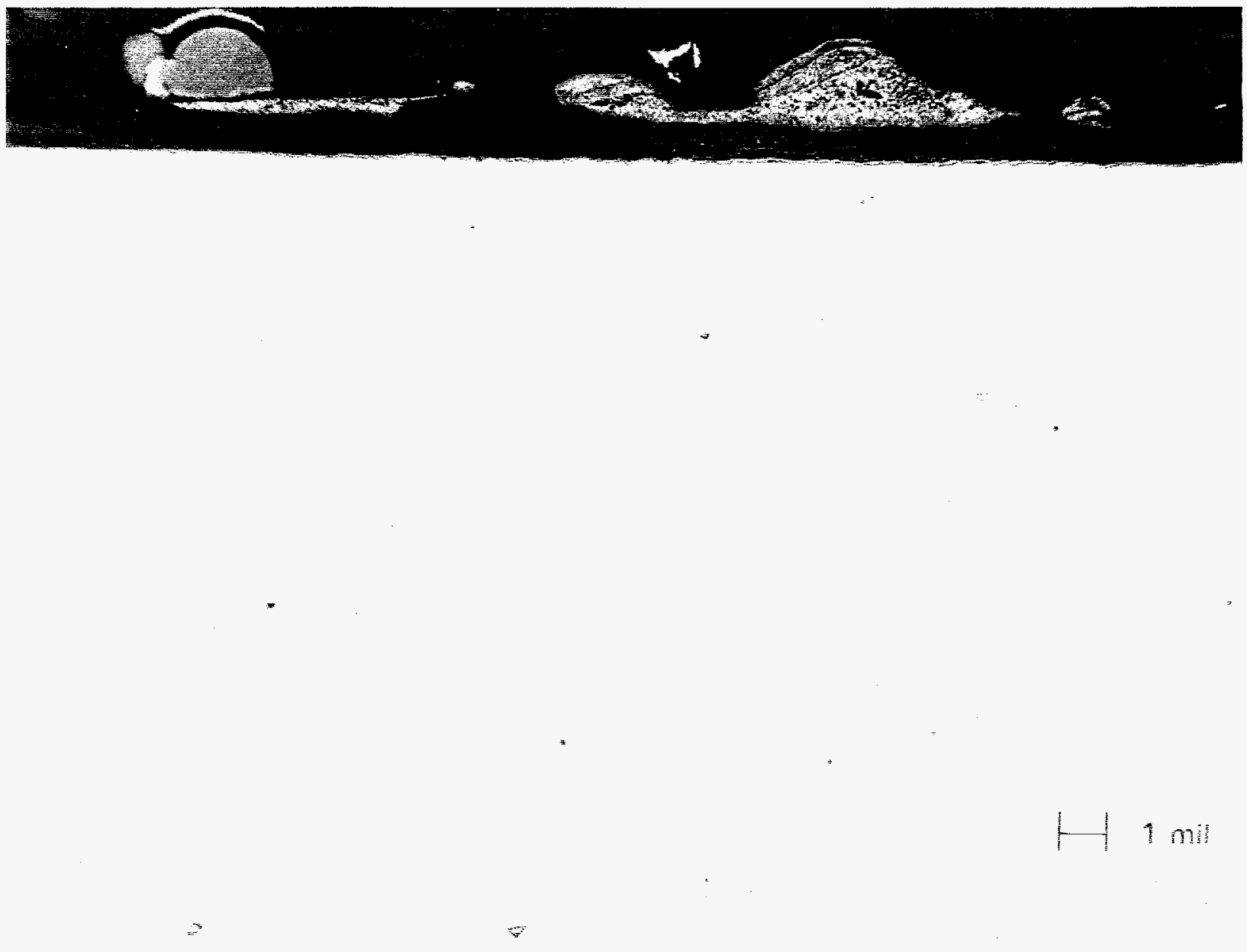

0

3

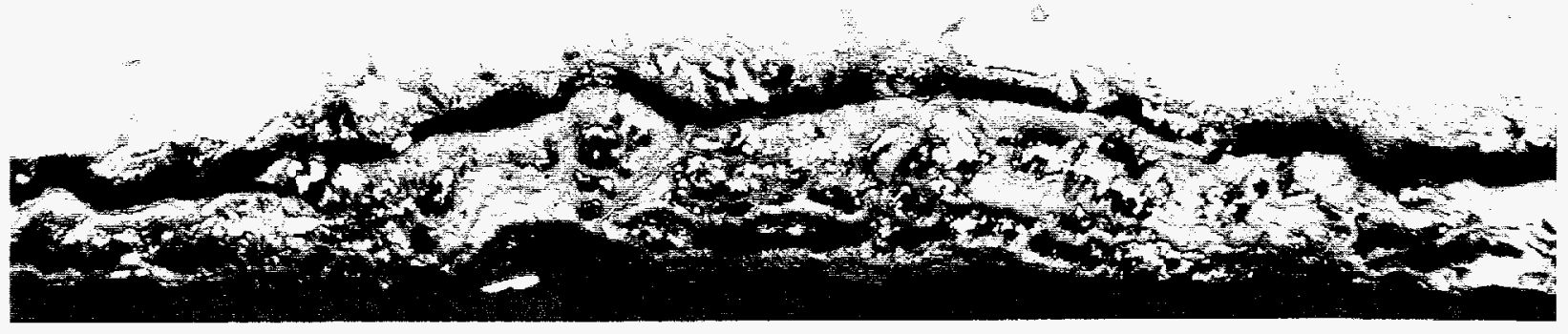

Fig. 21. Only the ID attack of the lean stainless steel base material can be seen on the 671-16 sample. 

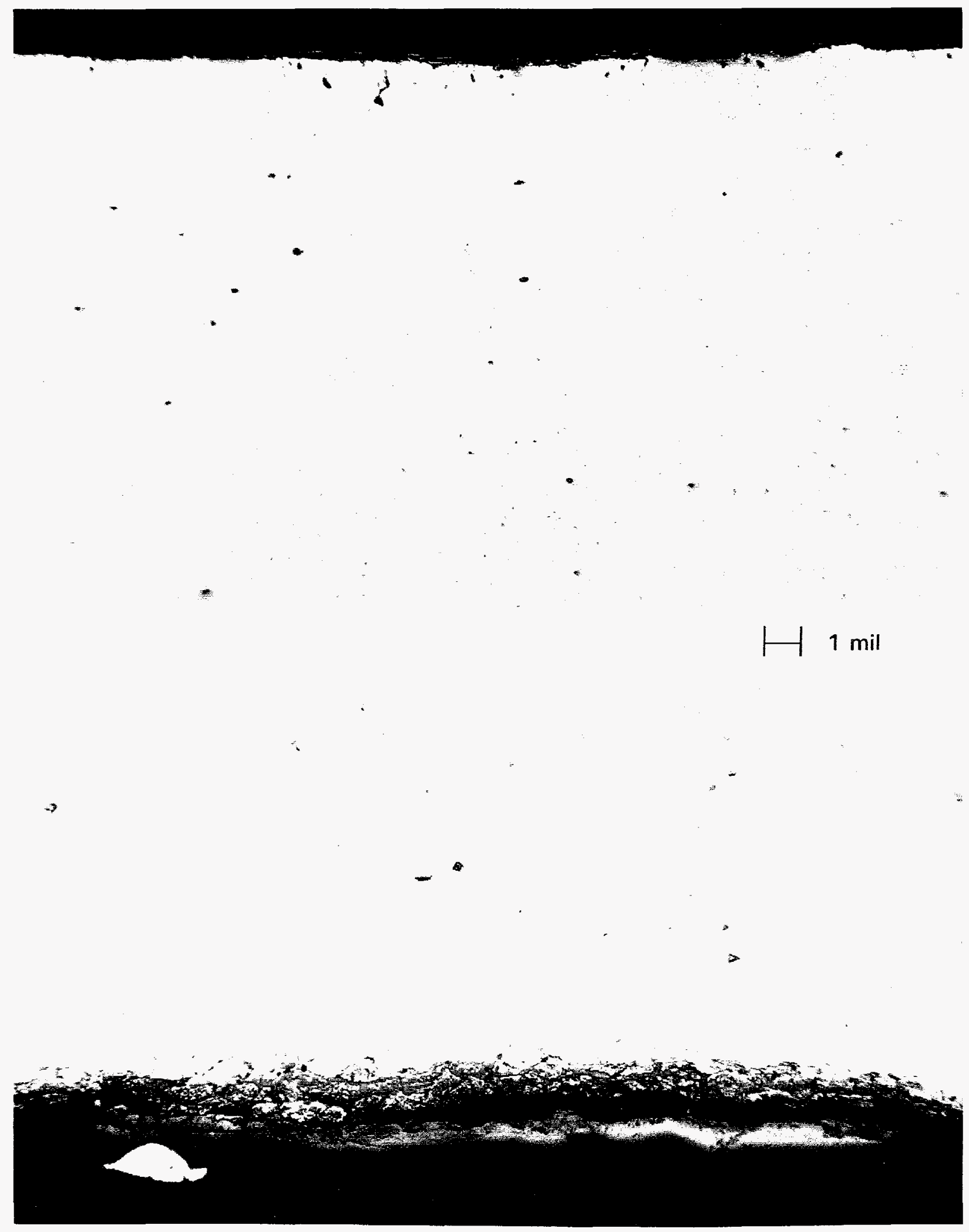

Fig. 22. One mil of internal oxidation was observed on the OD of 690-17 (top). The ID attack of the lean stainless steel can be seen in the bottom photomicrograph. 


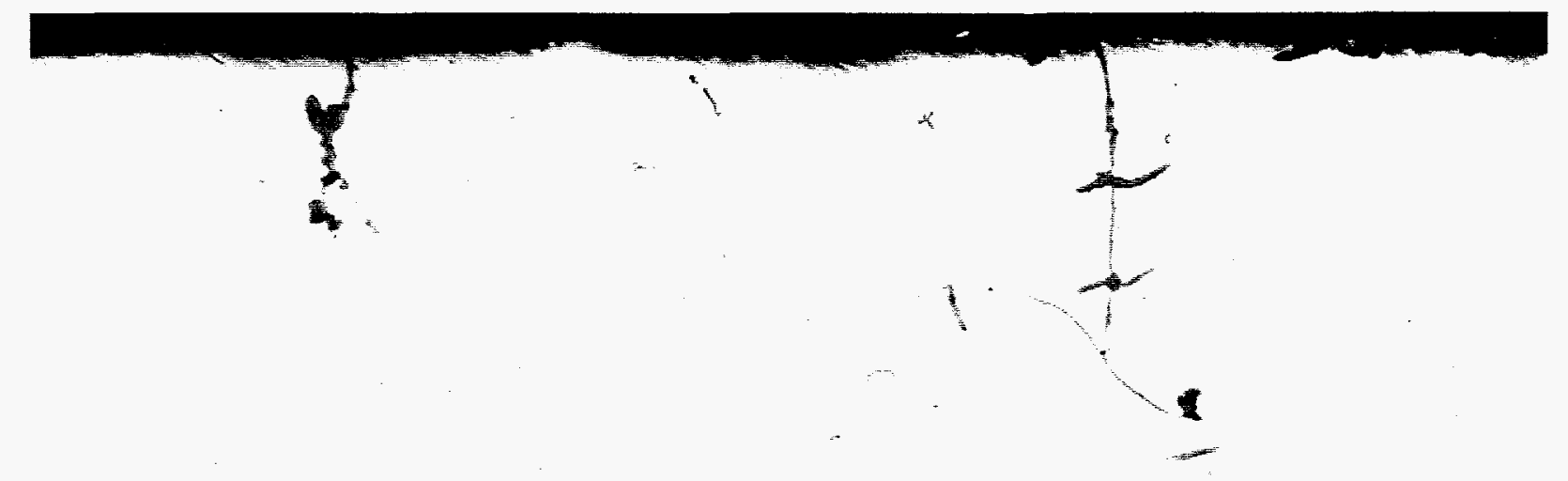
$\mathrm{Fe}_{3} \mathrm{Al}-8$
$11 \mathrm{mil}$

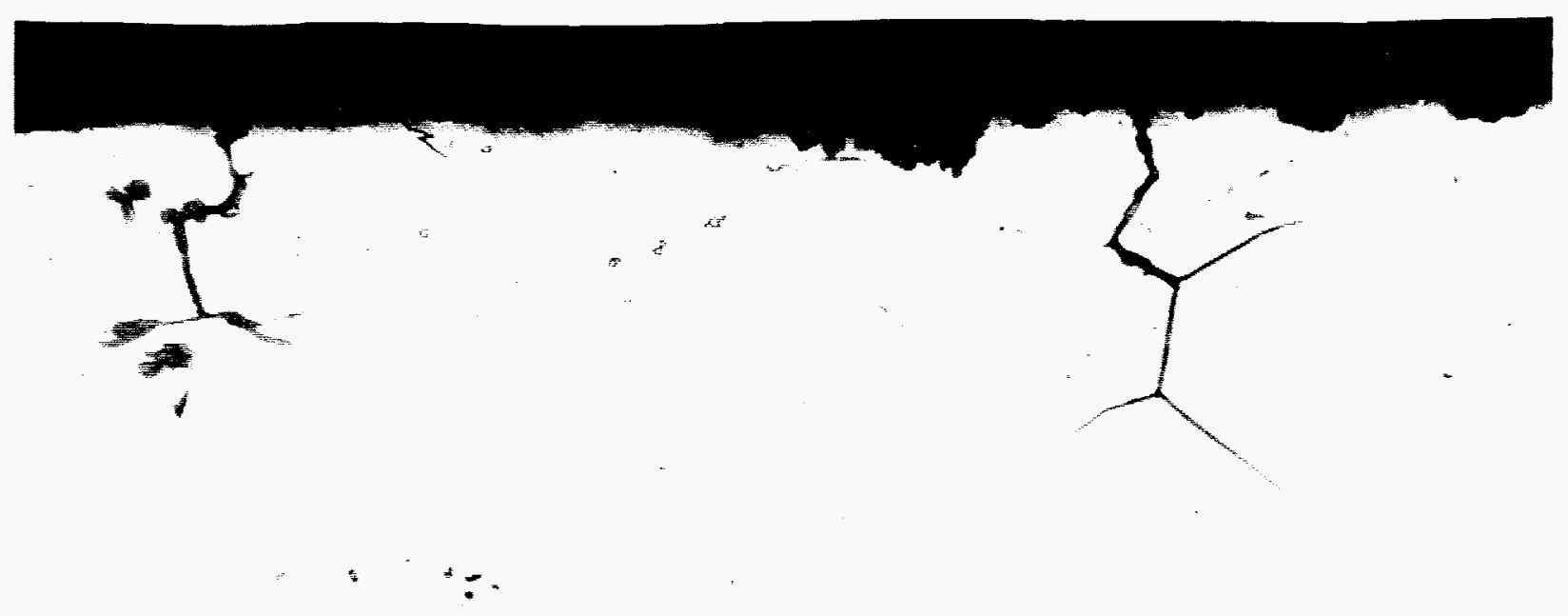

$\mathrm{Fe}_{3} \mathrm{Al}-18$

$1 \mathrm{mil}$

Fig. 23. Some slight surface attack can be seen on the $\mathrm{Fe}_{3} \mathrm{Al}-18$ sample. Also, cracks up to 5 mils deep can be seen in both samples. 


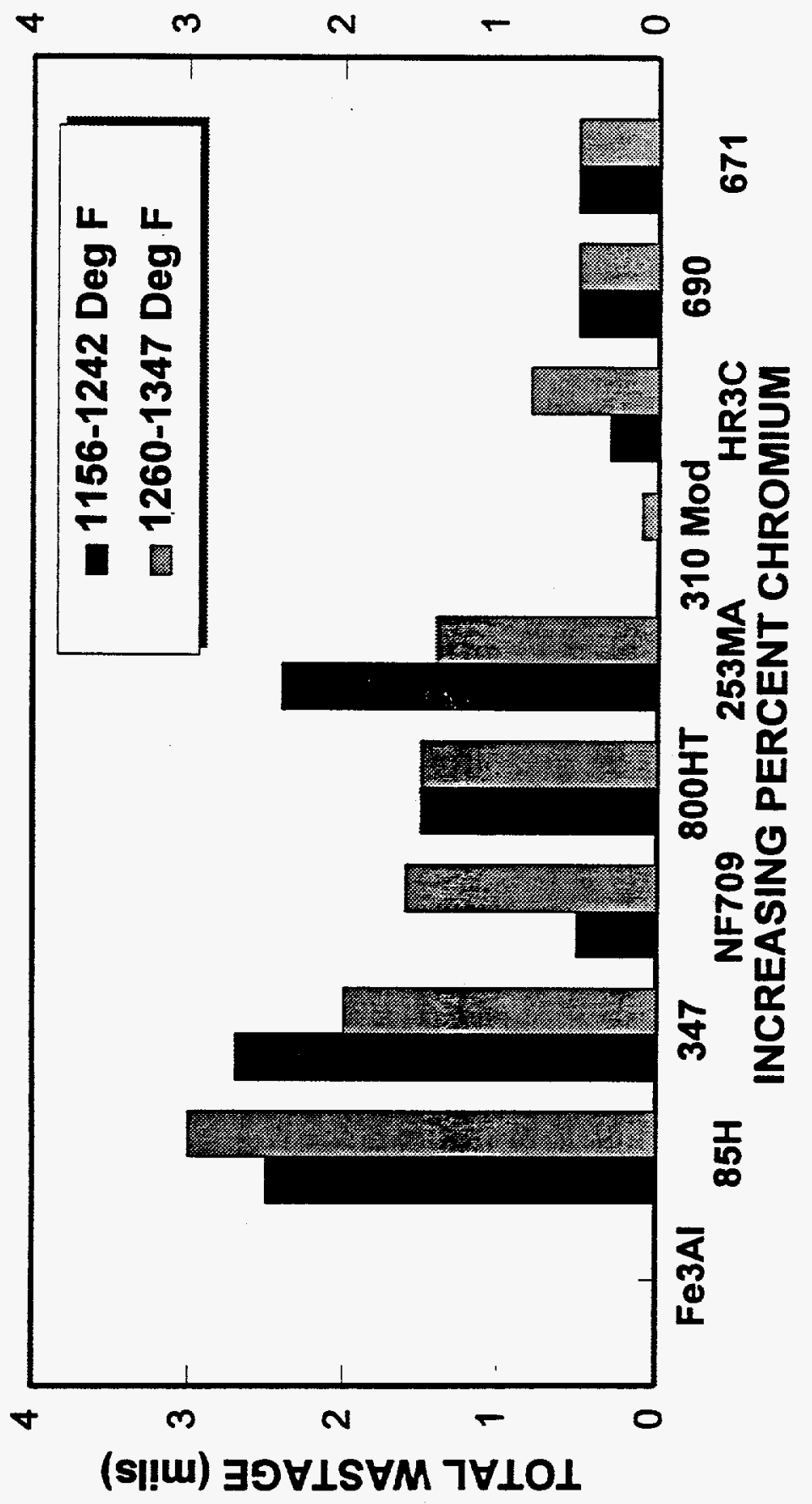


ABB POWER PLANT LABORATORIES

2000 Day Hill Road

P. O. Box 500

Windsor, CT 06095

A. Plumley

AIR PRODUCTS AND CHEMICALS, INC.

P. O. Box 538

Allentown, PA 18105

K. Baumert

S. W. Dean

ALBERTA RESEARCH COUNCIL

Oil Sands Research Department

P. O. Box 8330 - Postal Station F

Edmonton, Alberta, Canada T6H 5X2

L. G. S. Gray

ALLISON GAS TURBINE DIVISION

P. O. Box 420

Indianapolis, IN 46206-0420

P. Khandelwal (Speed Code W-5)

R. A. Wenglarz (Speed Code W-16)

AMOCO CORPORATION

Warrenville Road and Mill Street

P. O. Box 400

Naperville, IL 60566

S. Ibarra

ARGONNE NATIONAL LABORATORY

9700 S. Cass Avenue

Argonne, IL 60439

K. Natesan

BABCOCK \& WILCOX

Domestic Fossil Operations

20 South Van Buren Avenue

Barberton, OH 44023

P. Daniel

M. Gold

BRITISH COAL CORPORATION

Coal Technology Development Division

Stoke Orchard, Cheltenham

Glocestershire, England GL52 4ZG

J. Oakey
CANADA CENTER FOR MINERAL \& ENERGY

TECHNOLOGY

568 Booth Street

Ottawa, Ontario, Canada K1A OG1

R. Winston Revie

Mahi Sahoo

DOE

DOE OAK RIDGE OPERATIONS

P. O. Box 2001

Oak Ridge, TN 37831

Assistant Manager for Energy Research and Development

DOE

DOE OAK RIDGE OPERATIONS

P. O. Box 2008

Building 4500N, MS 6269

Oak Ridge, TN 37831

M. H. Rawlins

DOE

MORGANTOWN ENERGY TECHNOLOGY

CENTER

P. O. Box 880

Morgantown, WV 26505

R. C. Bedick

D. C. Cicero

F. W. Crouse, Jr.

N. T. Holcombe

W. J. Huber

J. E. Notestein

DOE

OFFICE OF FOSSIL ENERGY

FE-72

19901 Germantown Road

Germantown, MD 20874-1290

J. P. Carr

DOE

OFFICE OF BASIC ENERGY SCIENCES

Materials Sciences Division

ER-131, GTN

Washington, DC 20545

H. M. Kerch 
DOE

PITTSBURGH ENERGY TECHNOLOGY CENTER

P. O. Box 10940

Pittsburgh, PA 15236

A. L. Baldwin

G. V. McGurl

T. M. Torkos

ELECTRIC POWER RESEARCH INSTITUTE

P. O. Box 10412

3412 Hillview Avenue

Palo Alto, CA 94303

W. T. Bakker

J. Stringer

EUROPEAN COMMUNITIES JOINT RESEARCH

CENTRE

Petten Establishment

P. O. Bax 2

1755 ZG Petten

The Netherlands

M. Van de Voorde

\section{FOSTER WHEELER DEVELOPMENT}

CORPORATION

Materials Technology Department

John Blizard Resarch Center

12 Peach Tree Hill Road

Livingston, NJ 07039

J. L. Blough

HAYNES INTERNATIONAL, INC.

1020 West Park Avenue

P. O. Box 9013

Kokomo, IN 46904

G. Lai

IDAHO NATIONAL ENGINEERING LABORATORY

P. O. Box 1625

Idaho Falls, ID 83415

A. B. Denison

R. N. Wright

INCO ALLOYS INTERNATIONAL, INC.

P. O. Box 1958

Huntington, WV 25720

P. Ganesan

ISHIKAWAJIMA-HARIMA HEAVY INDUSTRIES

CO., LTD.

2-16, Toyosu, 3-Chome,

Koto-Ku, Tokyo, 135, Japan

S. Kihara
LAWRENCE LIVERMORE NATIONAL

LABORATORY

P. O. Box 808, L-325

Livermore, CA 94550

W. A. Steele

LEHIGH UNIVERSITY

Materials Science \& Engineering

Whitaker Laboratory

5 East Packer Avenue

Bethlehem, PA 18015

John N. DuPont

MOBIL RESEARCH \& DEVELOPMENT

CORPORATION

P. O. Box 1026

Princeton, NJ 08540

R. C. Searles

NATIONAL MATERIALS ADVISORY BOARD

National Research Council

2101 Constitution Avenue

Washington, DC 20418

K. M. Zwilsky

OAK RIDGE NATIONAL LABORATORY

P. O. Box 2008

Oak Ridge, TN 37831

P. T. Carlson

N. C. Cole

F. D. Johnson (5 copies)

R. R. Judkins

D. P. Stinton

P. F. Tortorelli

M. R. Upton

I. G. Wright

RISOE NATIONAL LABORATORY

P. O. Box 49

DK-4000

Roskilde, Denmark

Aksel Olsen

ROLLED ALLOYS INC.

125 West Sterns Road

P. O. Box 310

Temperance, MI 48182

K. Kelly

SANDVIK STEEL CO.

Tubular Products Division

P. O. Box 1220

Scranton, PA 18501

J. Noble 
SHELL DEVELOPMENT COMPANY

P. O. Box 1380

Houston, TX 77251-1380

L. W. R. Dicks

R. John

SOUTHWEST RESEARCH INSTITUTE

6620 Culebra Road

P. O. Drawer 28510

San Antonio, TX 78284

F. F. Lyle, Jr.

SUMITOMO METAL USA CORPORATION

8750West Bryn Mawr Avenue

Suite 1000

Chicago, IL 60631

A. Iseda

TENNESSEE VALLEY AUTHORITY

1101 Market Streeet

Chattanooga, TN 37402-2801

P. Chang

J. Denton Eady

TENNESSEE VALLEY AUTHORITY

1101 Market Streeet

3A Missionary Ridge Place

Chattanooga, TN 37402-2801

A. M. Manaker

TENNESSEE VALLEY AUTHORITY

Energy Demonstration \& Technology

MR 2N58A

Chattanooga, TN 37402-2801

C. M. Huang

TENNESSEE VALLEY AUTHORITY

1101 Market Streeet

3N 66A Missionary Ridge Place

Chattanooga, TN 37402-2801

J. Brooks

\section{TENNESSEE VALLEY AUTHORITY}

Gallatin Steam Plant

1499 Steam Plant Road

Gallatin, TN 37066

J. Hollins

THE MATERIALS PROPERTIES COUNCIL, INC.

United Engineering Center

345 East 47th Street

New York, NY 10017

M. Prager
UNIVERSITY OF TENNESSEE AT KNOXVILLE

Materials Science and Engineering Department Knoxville, TN 37996

R. A. Buchanan

C. D. Lundin

WESTERN RESEARCH INSTITUTE

365 North 9th Street

P. 0. Box 3395

University Station

Laramie, WY 82071

V. K. Sethi

WESTINGHOUSE ELECTRIC CORPORATION Research and Development Center 1310 Beulah Road

Pittsburgh, PA 15235

S. C. Singhal 